2020-07-28

Drying shrinkage, strength and microstructure of alkali-activated high-calcium fly ash using FGD-gypsum and dolomite as expansive additive

Hanjitsuwan, S

http://hdl.handle.net/10026.1/16111

10.1016/j.cemconcomp.2020.103760

Cement and Concrete Composites

Elsevier BV

All content in PEARL is protected by copyright law. Author manuscripts are made available in accordance with publisher policies. Please cite only the published version using the details provided on the item record or document. In the absence of an open licence (e.g. Creative Commons), permissions for further reuse of content should be sought from the publisher or author. 
Cement and Concrete Composites.

Received 8 May 2020, Revised 12 July 2020, Accepted 20 July 2020, Available online 28 July 2020

https://doi.org/10.1016/j.cemconcomp.2020.103760

\title{
Drying Shrinkage, Strength, and Microstructure of Alkali-Activated High- Calcium Fly Ash using FGD-gypsum and Dolomite as Expansive Additive
}

Sakonwan Hanjitsuwan ${ }^{\mathrm{a}^{*}}$, Borwonrak Injorhor ${ }^{\mathrm{b}}$, Tanakorn Phoo-ngernkham ${ }^{\mathrm{b} * *}$,

Long-Yuan $\mathrm{Li}^{\mathrm{c}}$, Nattapong Damrongwiriyanupap ${ }^{\mathrm{d}}$, Piti Sukontasukkul ${ }^{\mathrm{e}}$, and Prinya Chindaprasirt ${ }^{\mathrm{f}, \mathrm{g}}$

${ }^{a}$ Program of Civil Technology, Faculty of Industrial Technology, Lampang Rajabhat University, Lampang 52100, Thailand

${ }^{b}$ Sustainable Construction Material Technology Research Unit, Department of Civil Engineering, Faculty of Engineering and Architecture, Rajamangala University of Technology Isan, Nakhon Ratchasima 30000, Thailand

${ }^{c}$ School of Engineering, Faculty of Science and Engineering, Plymouth University, PL4 8AA, United of Kingdom

${ }^{d}$ Civil Engineering Program, School of Engineering, University of Phayao, Phayao 56000, Thailand

${ }^{e}$ Construction and Building Materials Research Center, Department of Civil Engineering, Faculty of Engineering, King Mongkut's University of Technology-North Bangkok, Bangkok 10800, Thailand

${ }^{f}$ Sustainable Infrastructure Research and Development Center, Department of Civil Engineering, Faculty of Engineering, Khon Kaen University, Khon Kaen 40002, Thailand ${ }^{g}$ Academy of Science, The Royal Society of Thailand, Dusit, Bangkok 10300, Thailand

\begin{abstract}
This paper aims to investigate drying shrinkage, strength development, and microstructure of alkali-activated high-calcium fly ash (AAFA) paste by using FGD-gypsum
\end{abstract}


(FGD) and dolomite (DLM) as the expansive additive. The 10 molar of sodium hydroxide combined with sodium silicate solutions were used as liquid alkaline activation in all mixtures. The preparation of the AAFA paste was divided into 2 steps. First, the study was focused on the effects of expansive additive (FGD and DLM) and liquid/binder (L/B) ratio on the drying shrinkage of the AAFA paste. The FA was replaced by FGD and DLM at the dosages of $0 \%, 2.5 \%, 5.0 \%, 7.5 \%$, and $10 \%$ by weight of binder. The AAFA paste with low drying shrinkage at the age of 90 days would be selected to further study. The other was to study setting time, compressive strength, and microstructure of the AAFA paste containing FGD and DLM. Test results indicated that the use of FGD and DLM as the expansive additive could improve the drying shrinkage of the AAFA paste. The increasing L/B ratio had adverse effects on its drying shrinkage. The setting time of the AAFA paste containing FGD and DLM had decreased, whereas its strength development had increased. However, the strength development of the AAFA paste incorporated with FGD tended to decline at the curing time of 120 days. These behaviors were consistent with the results of XRD, FTIR, and SEM/EDS analyses. The differences in reaction products were an essential factor in the strength development of the AAFA paste with expansive additive. It can be recommended that using DLM was advantages regarding the improvement of drying shrinkage and longterm strength in comparison with the AAFA paste with FGD.

Keywords: Alkali-activated binder, High-calcium fly ash, Expansive additive, Drying shrinkage, Strength development, Microstructure

\footnotetext{
* Corresponding author. Tel: +66 5423 7352; Fax: +66 5423 7388; E-mail address: sakonwan@lpru.ac.th

** Corresponding author. Tel: +66 44233000 ext.3210; E-mail address: tanakorn.ph@rmuti.ac.th
}

\section{Introduction}


Nowadays, Portland cement (PC) is a popular choice for use as a cementitious material in the construction industry. This is because the PC provided good mechanical properties and low-cost advantages. Besides, this PC could be used as the precursor for manufacturing the polymer-modified cement for repairing damaged concrete structures [1]. However, it is well known that $\mathrm{PC}$ is a primary problem of global warming, which causes a high amount of $\mathrm{CO}_{2}$ emission. Turner and Collins [2] and Mclellan et al. [3] reported that every 1 ton of PC released approximately 1 ton of $\mathrm{CO}_{2}$. This is why the amount of greenhouse gas in the atmosphere tends to increase every year. To solve this issue, a number of researchers [4-6] attempted to reduce the PC content for producing the concrete. Sata et al. [4] studied on the use of by-product viz., ground pulverized coal combustion fly ash, ground fluidized bed combustion fly ash, ground rice husk ash, and ground palm oil fuel ash to investigate mechanical properties of high-strength concrete. They reported that these pozzolanic materials could enhance the strength development of concrete. Detphan et al. [6] reported that the use of high-calcium fly ash (FA) and expanded perlite to replace PC could improve the strength and water retention requirements for masonry and rendering mortar as per ASTM standard. However, the PC is still widely used for producing the mortar and concrete. Therefore, the new eco-friendly cement is extensively studied in order to reduce the $\mathrm{CO}_{2}$ footprint. One of them is the alkali-activated binders that could produce from precursors consisting of $\mathrm{Si}^{4+}$ and $\mathrm{Al}^{3+}$ ions activated with a high alkali solution [7, 8]. Many researchers [9-12] reported that the alkali-activated binders provided excellent mechanical and durability properties. Besides, alkali-activated binders showed a lower $\mathrm{CO}_{2}$ footprint than those of PC and epoxy-resin.

Pacheco-Torgal et al. [13] revealed that the alkali-activated binders could be classified into two systems: low- and high- calcium system. The former, also known as geopolymer, is generally obtained from the activation of low-calcium materials and high alkaline solutions. 
The sodium aluminosilicate hydrate $(\mathrm{N}-\mathrm{A}-\mathrm{S}-\mathrm{H})$ gel is the main reaction product, in which low strength when cured at ambient temperature was obtained [14]. For the latter, precursors such as slag and high-calcium FA activated with medium alkali solutions. The main reaction products of high-calcium based are calcium silicate hydrate (C-S-H) and calcium aluminosilicate hydrate (C-A-S-H) coexisted with sodium aluminosilicate hydrate (N-A-S-H) gel [15]. The occurrence of C-S-H in the alkali-activated binders is suitable to use in real construction because it could be provided the high strength when cured at ambient temperature.

In Thailand, high-calcium FA from Mae Moh power station is widely used for producing alkali-activated binders. The studies of Phoo-ngernkham et al. [16] and Phoongernkahm et al. [17] have shown that the use of FA with additives exhibited the early strength development like the PC system. Thus, it could be used as repair material described in previous studies $[10-12,18]$. Note that the properties of repair material in terms of rapid setting, high strength, high bonding, and high durability are needed. However, some researchers $[19,20]$ reported that the shrinkage behavior of alkali-activated high-calcium FA showed a very high value when cured at ambient temperature. Ma et al. [21] have found that the shrinkage behavior is a critical property that caused the cracking probability of alkaliactivated binders under the restrained condition, and hence long term durability problems occurred. Therefore, this may be a limitation of using alkali-activated high-calcium FA as the repair material, although it exhibited high bonding and excellent durability. Generally, alkaliactivated binders had much higher autogenous and drying shrinkage than the PC system [21]. However, the test results of Ridtirud et al. [19] and Fernandez-Jimenez et al. [22] showed that the drying shrinkage of heat-cured alkali-activated binders was much lower than that of PC, indicating that different curing conditions could influence the drying shrinkage of alkaliactivated binders. The improvement of drying shrinkage of alkali-activated binders has been 
studied by several researchers. Matalkah et al. [23] improved the drying shrinkage of alkaliactivated cement by using 5\%wt silica fume, 2.5\%wt Polyethylene glycol, 5\%wt gypsum, and 5\%wt limestone powder. Bakharev et al. [24] reported that using $6 \%$ by weight of gypsum could reduce both autogenous and drying shrinkage of alkali-activated slag because the formation of ettringite acted as the expansive phase. Besides, the use of carbonate mineral viz., calcite and dolomite could reduce the drying shrinkage of low-calcium based geopolymers as reported by Yip et al. [25] and Cohen et al. [26]. Their results revealed that the formations of calcium carbonate $\left(\mathrm{CaCO}_{3}\right)$, magnesium hydroxide $\left(\mathrm{Mg}(\mathrm{OH})_{2}\right)$ and sodium carbonate $\left(\mathrm{Na}_{2} \mathrm{CO}_{3}\right)$ were taken place and hence its drying shrinkage reduced. Hwang et al. [27] and Jin et al. [28] also investigated the shrinkage compensation of alkali-activated slag using reactive $\mathrm{MgO}$ as the expansive additive. It is found that using $\mathrm{MgO}$ in alkali-activated slag produced the reaction products that acted as the expansive phase. In addition, Punurai et al. [20] improved the drying shrinkage of alkali-activated high-calcium FA by using basalt fiber.

From the above review, there is no research investigated on the use of FGD-gypsum and dolomite as the expansive additive to improve the drying shrinkage of alkali-activated high-calcium FA. Thus, this research focuses mainly on the utilization of FGD-gypsum and dolomite as the expansive additive for improving the drying shrinkage and strength development of alkali-activated high-calcium FA. The obtained knowledge of this study would be very beneficial to understand the shrinkage compensation of alkali-activated highcalcium FA by using FGD-gypsum and dolomite as the expansive additive.

\section{Experimental details}

\subsection{Materials}


High-calcium FA from Mae Moh power plant in northern Thailand was used as the main precursor to produce alkali-activated binder. FA had specific gravity and median particle size of 2.65 and $15.3 \mu \mathrm{m}$, respectively. The FGD-gypsum (FGD) and dolomite (DLM) were used as the expansive additive (EA) for shrinkage compensation material. FGD is the by-product from Mae Moh power plant in northern Thailand, whereas the DLM is an anhydrous carbonate mineral. Both of FGD and DLM were oven-dried at $100^{\circ} \mathrm{C}$ for 24 hours and then passed through a sieve No. $100(150 \mu \mathrm{m})$ before used as the precursor. FGD and DLM had specific gravity of 2.64 and 2.79 , respectively. The chemical compositions of FA, FGD and DLM are shown in Table 1. The FA had sum of $\mathrm{SiO}_{2}+\mathrm{Al}_{2} \mathrm{O}_{3}+\mathrm{Fe}_{2} \mathrm{O}_{3}$ at $66.94 \%$ and $\mathrm{CaO}$ at $21.41 \%$. Therefore, this FA was classified as class C FA as per ASTM C618 [29]. The major components of FGD are $\mathrm{CaO}$ and $\mathrm{SO}_{3}$ at $32.84 \%$ and $48.47 \%$, whereas the DLM mainly consists of $\mathrm{SiO}_{2}$ and $\mathrm{CaO}$ at $10.64 \%$ and $44.55 \%$, respectively. Figure 1 shows the mineral compositions of the FGD and DLM as determined by XRD analysis. The FGD consists of crystal of gypsum $\left(\mathrm{CaSO}_{4} \cdot 2 \mathrm{H}_{2} \mathrm{O}\right)$ and calcium sulfate hemihydrate $\left(\mathrm{CaSO}_{4} \cdot 0.5 \mathrm{H}_{2} \mathrm{O}\right)$, whereas the DLM contains crystal phase of calcium carbonate $\left(\mathrm{CaCO}_{3}\right)$ and dolomite $\left(\mathrm{CaMg}\left(\mathrm{CO}_{3}\right)_{2}\right)$. In addition, the SEM images of FGD and DLM are shown in Figure 2.

Table 1 Chemical compositions of FA, FGD, and DLM (by weight)

\begin{tabular}{cccccccccccccc}
\hline \multirow{2}{*}{ Materials } & \multicolumn{10}{c}{ Chemical compositions (\%) } \\
\cline { 2 - 13 } & $\mathrm{SiO}_{2}$ & $\mathrm{Al}_{2} \mathrm{O}_{3}$ & $\mathrm{Fe}_{2} \mathrm{O}_{3}$ & $\mathrm{CaO}$ & $\mathrm{MgO}$ & $\mathrm{K}_{2} \mathrm{O}$ & $\mathrm{Na}_{2} \mathrm{O}$ & $\mathrm{TiO}_{2}$ & $\mathrm{P}_{2} \mathrm{O}_{5}$ & other & $\mathrm{SO}_{3}$ & $\mathrm{LOI}$ \\
& 36.93 & 18.10 & 11.91 & 21.41 & 2.78 & 2.28 & 1.42 & 0.36 & 0.20 & 0.16 & 2.90 & 1.54 \\
FA & 0.73 & 0.42 & 0.09 & 32.84 & 0.76 & 0.01 & 0.17 & 0.03 & 0.04 & 0.01 & 48.47 & 16.44 \\
FGD & 10.64 & 1.19 & 0.47 & 44.55 & 3.09 & 0.15 & 0.03 & 0.06 & 0.05 & 0.06 & 0.13 & 39.57
\end{tabular}




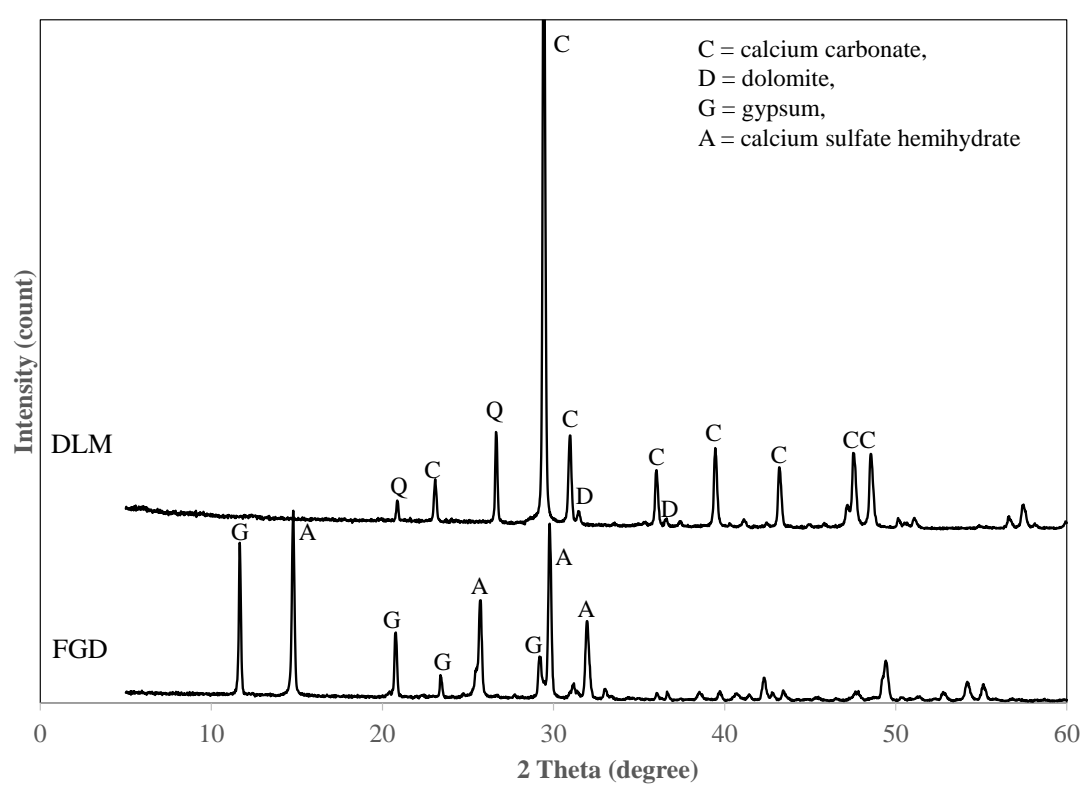

Figure 1 XRD patterns of FGD and DLM

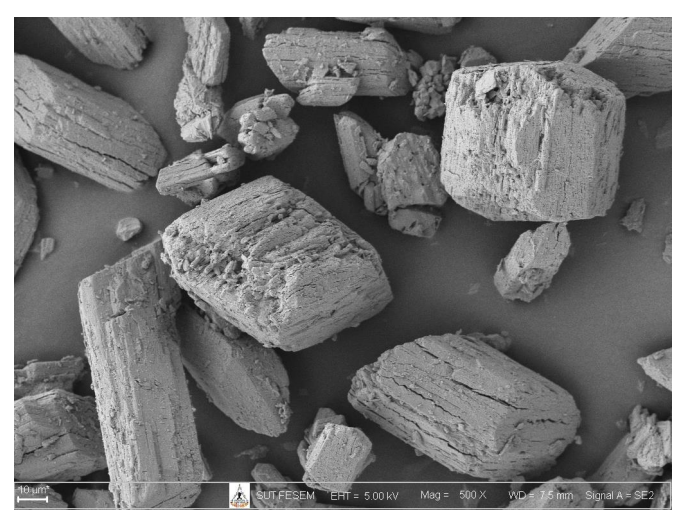

(a) FGD

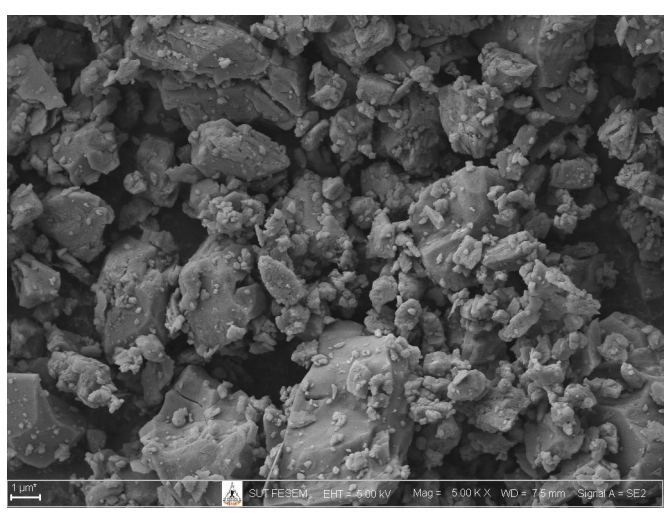

(b) DLM

Figure 2 SEM images of FGD and DLM

\subsection{Mix proportions}

The mix proportions of alkali-activated FA (AAFA) paste with expansive additive are summarized in Table 2. The 10 molar of sodium hydroxide $(\mathrm{NaOH})$ and sodium silicate $\left(\mathrm{Na}_{2} \mathrm{SiO}_{3}\right)$ with $13.89 \% \mathrm{Na}_{2} \mathrm{O}, 32.15 \% \mathrm{SiO}_{2}$, and $53.96 \% \mathrm{H}_{2} \mathrm{O}$ were used as liquid activators with constant $\mathrm{Na}_{2} \mathrm{SiO}_{3} / \mathrm{NaOH}$ ratio of 1.0. In this study, preparation of the AAFA paste with the expansive additive was divided into 2 steps as follows: 
(1) The expansive additive (FGD and DLM) was used to replace FA at the amount of $0 \%, 2.5 \%, 5.0 \%, 7.5 \%$, and $10 \%$ by weight of binder. The differences in liquid/binder (L/B) ratios of $0.40,0.50$, and 0.60 were investigated. After testing, the best result of 90-day drying shrinkage of the AAFA paste with expansive additive (FGD and DLM) was considered for conducting the next step.

(2) As mentioned, the L/B ratio of the AAFA paste with the expansive additive is chosen regarding the lowest drying shrinkage. Then, the setting time, compressive strength, and microstructure of the AAFA paste with expansive additive are tested and examined.

Table 2 Mix proportions of alkali-activated FA paste with expansive additive

\begin{tabular}{cccccc}
\hline No. & Symbol & $\mathrm{FA}(\mathrm{g})$ & $\mathrm{EA}(\mathrm{g})$ & $\mathrm{NaOH}(\mathrm{g})$ & $\mathrm{Na}_{2} \mathrm{SiO}_{3}(\mathrm{~g})$ \\
\hline 1 & $0.4 \mathrm{LB} 100 \mathrm{FA}$ & 100.0 & - & 20 & 20 \\
2 & $0.4 \mathrm{LB} 2.5 \mathrm{EA}$ & 97.5 & 2.5 & 20 & 20 \\
3 & $0.4 \mathrm{LB} 5.0 \mathrm{EA}$ & 95.0 & 5.0 & 20 & 20 \\
4 & $0.4 \mathrm{LB} 7.5 \mathrm{EA}$ & 92.5 & 7.5 & 20 & 20 \\
5 & $0.4 \mathrm{LB} 10 \mathrm{EA}$ & 90.0 & 10.0 & 20 & 20 \\
\hline 6 & $0.5 \mathrm{LB} 100 \mathrm{FA}$ & 100.0 & - & 25 & 25 \\
7 & $0.5 \mathrm{LB} 2.5 \mathrm{EA}$ & 97.5 & 2.5 & 25 & 25 \\
8 & $0.5 \mathrm{LB} 5.0 \mathrm{EA}$ & 95.0 & 5.0 & 25 & 25 \\
9 & $0.5 \mathrm{LB} 7.5 \mathrm{EA}$ & 92.5 & 7.5 & 25 & 25 \\
10 & $0.5 \mathrm{LB} 10 \mathrm{EA}$ & 90.0 & 10.0 & 25 & 25 \\
\hline 11 & $0.6 \mathrm{LB} 100 \mathrm{FA}$ & 100.0 & - & 30 & 30 \\
12 & $0.6 \mathrm{LB} 2.5 \mathrm{EA}$ & 97.5 & 2.5 & 30 & 30 \\
13 & $0.6 \mathrm{LB} 5.0 \mathrm{EA}$ & 95.0 & 5.0 & 30 & 30 \\
14 & $0.6 \mathrm{LB} 7.5 \mathrm{EA}$ & 92.5 & 7.5 & 30 & 30 \\
15 & $0.6 \mathrm{LB} 10 \mathrm{EA}$ & 90.0 & 10.0 & 30 & 30 \\
\hline & & & & 25 & 30 \\
\hline
\end{tabular}

For the mixing of the paste, $\mathrm{NaOH}$ and $\mathrm{Na}_{2} \mathrm{SiO}_{3}$ solutions were firstly mixed together before use as the liquid alkaline activators. The FA and expansive additive (FGD and DLM) 
were dry mixed until the mixture was almost homogenous. After that, liquid alkaline activators was added into the mixture and the mixing was done for 2 minutes.

\subsection{Testing procedure}

\subsubsection{Drying shrinkage}

After mixing, a fresh AAFA paste was placed into a $25 \times 25 \times 285 \mathrm{~mm}^{3}$ prism mold following ASTM C490 [30] and ASTM C596 [31]. The shrinkage specimens were demolded after ambient temperature curing for 24 hours and then they were measured as the first length. Then, the specimens were kept in a control room of $25 \pm 2{ }^{\circ} \mathrm{C}$ with a relative humidity of $50 \pm 5 \%$. The length changes were measured daily for the first 2 weeks and then once a week until a month. After that, they were measured every month until 360 days. The test set-up of drying shrinkage specimens using digital micrometer apparatus is shown in Figure 3.

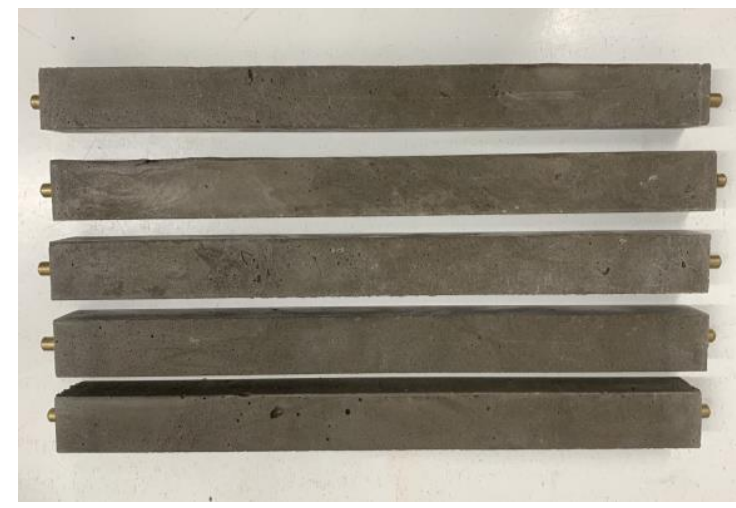

(a) specimens

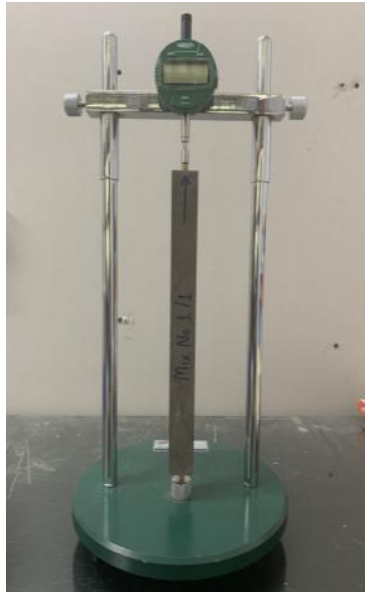

(b) Length change test apparatus

Figure 3 Test set-up of drying shrinkage specimens

\subsubsection{Setting time and compressive strength}

The setting time of the AAFA paste with expansive additive was evaluated using the Vicat apparatus in accordance with ASTM C191 [32]. For the compressive strength test, the 
fresh AAFA pastes were placed into a 50x50x50 $\mathrm{mm}^{3}$ cube mold and compacted as per ASTM C109 [33]. After that, a cube mold was immediately wrapped with vinyl sheet to protect moisture loss for 24 hours. They were demolded and then immediately wrapped using vinyl sheet and kept in ambient temperature until testing ages of 7, 28, 60, 90, 120, and 180 days. Five samples were tested for each case and their average value was used as the reported experimental result.

\subsubsection{XRD, SEM, FTIR analyses}

To study the evolution of the growth of cementitious products in AAFA paste with expansive additive, microstructure evaluation techniques viz., X-ray diffractometry (XRD), scanning electron microscopic (SEM), Fourier transform infrared spectroscopy (FTIR), were conducted. After the compressive strength was done at the age of 90 days, the specimens were broken into small pieces approximately 3-6 $\mathrm{mm}$ for SEM analysis. Besides, the specimens were ground into fine powder for XRD and FTIR analyses. The 2 theta between 10 and $60^{\circ}$ were performed to analyze the phase formation in the XRD [34], whereas the wave number region between 400 and $4000 \mathrm{~cm}^{1}$ was conducted for the FTIR.

\section{Results and Discussion}

\subsection{Drying shrinkage}

Figure 4 shows the drying shrinkage of the AAFA paste using FGD and DLM as the expansive additive under different L/B ratios up to 360 days. Generally, the drying shrinkage of alkali-activated pastes is significant for tensile stress developed in the matrix [21]; therefore, a high drying shrinkage was related to the possibility of cracking for the samples. According to Figures 4-9, the drying shrinkage of the AAFA paste is remarkably reduced as the replacement levels of FGD and DLM increased. For example, the 90-day drying 
shrinkage of 0.40LB100FA, 0.40LB2.5FGD 0.40LB5.0FGD, and 0.40LB7.5FGD pastes are $12,076,10,460,9,422$, and $9,512 \times 10^{-6} \mathrm{~mm} / \mathrm{mm}$, whereas the 90-day drying shrinkage of 0.40LB2.5DLM, 0.40LB5.0DLM, 0.40LB7.5DLM and 0.40LB10DLM pastes are 9,756, $8,656,8,372$, and $12,484 \times 10^{-6} \mathrm{~mm} / \mathrm{mm}$, respectively. The high values of drying shrinkage of the AAFA paste are consistent with what was reported by Punurai et al. [20] and Yusuf et al. [35]. As reported by previous researchers, the 90-day drying shrinkage of FA geopolymer paste was approximately $30,000 \times 10^{-6} \mathrm{~mm} / \mathrm{mm}$ [20], whereas the 90-day drying shrinkage of alkali-activated paste made from ground blast-furnace slag with ultra-fine palm oil fuel ash was approximately $26,000 \times 10^{-6} \mathrm{~mm} / \mathrm{mm} \mathrm{[35].}$

According to Figures 4-9, the incorporation of FGD and DLM as the expansive additive is effective for compensating the drying shrinkage of the AAFA paste as expected. This is because of the expansion potential of FGD and DLM. As is shown in Table 1 and Figure 1, the FDG is mainly consisted of gypsum $\left(\mathrm{CaSO}_{4} \cdot 2 \mathrm{H}_{2} \mathrm{O}\right)$ and calcium sulfate hemihydrate $\left(\mathrm{CaSO}_{4} \cdot 0.5 \mathrm{H}_{2} \mathrm{O}\right)$, whereas the DLM mainly consisted of calcium carbonate $\left(\mathrm{CaCO}_{3}\right)$ and dolomite $\left(\mathrm{CaMg}\left(\mathrm{CO}_{3}\right)_{2}\right)$. This agrees with the previous report [23] on the enhancement of drying shrinkage of alkali-activated binders cured at room temperature by using gypsum $\left(\mathrm{CaSO}_{4} \cdot 2 \mathrm{H}_{2} \mathrm{O}\right)$ and limestone $\left(\mathrm{CaCO}_{3}\right)$. Punurai et al. [20] and Pangdaeng et al. [36] also claimed that additional C-S-H and/or C-A-S-H co-existed with N-A-S-H gel within the matrix could lead to the refinement of pore structure [20].

Regarding the effect of the L/B ratio on the behavior of drying shrinkage, it is found that the increasing L/B ratios are found to increase the drying shrinkage of the AAFA paste for all replacement levels of FGD and DLM. For example, the 90-day drying shrinkage of 0.40LB100FA， 0.40LB5FGD， 0.50LB100FA， 0.50LB5FGD， 0.60LB100FA， and 0.60LB5FGD pastes are $12,076,9,422,12,409,9,727,15,827$, and 13,976 x10-6 $\mathrm{mm} / \mathrm{mm}$, whereas the 90-day drying shrinkage of 0.40LB5DLM, 0.50LB5DLM, and 0.60LB5DLM 
pastes are $8,656,10,291$, and $12,307 \times 10^{-6} \mathrm{~mm} / \mathrm{mm}$, respectively. These results agreed with Ridtirud et al. [19] who reported that the excess of water content at a high L/B ratio, resulting in high porosity and high shrinkage. Moreover, a higher $\mathrm{Na}_{2} \mathrm{O}$ and $\mathrm{SiO}_{2}$ contents from $\mathrm{NaOH}$ and $\mathrm{Na}_{2} \mathrm{SiO}_{3}$ solutions exhibited a larger drying shrinkage of alkali-activated low-calcium FA [21].

A number of researchers had reported why using FGD and DLM could enhance the drying shrinkage of the AAFA paste. Chindaprasirt et al. [37] reported that the reaction of gypsum $\left(\mathrm{CaSO}_{4} \cdot 2 \mathrm{H}_{2} \mathrm{O}\right)$ in alkali solution produced calcium hydroxide $\left(\mathrm{Ca}(\mathrm{OH})_{2}\right)$ and sodium sulfate $\left(\mathrm{Na}_{2} \mathrm{SO}_{4}\right)$ as shown in Eq. (1). Chindaprasirt et al. [37] and Bakharev et al. [24] explained that ettringite formation $\left(\mathrm{Ca}_{6} \mathrm{Al}_{2}\left(\mathrm{SO}_{4}\right)_{3}(\mathrm{OH})_{12} \cdot 26 \mathrm{H}_{2} \mathrm{O}\right)$ would compensate for the shrinkage behavior of alkali-activated binders. Ettringite formation rate depended on the concentration of $\mathrm{OH}^{-}, \mathrm{SO}_{4}{ }^{2-}$, and $\mathrm{Ca}^{2+}$ in the liquid alkaline; therefore, less formation of ettringite was performed at high $\mathrm{NaOH}$ concentration [38]. According to Figures 4-6, the FA:FGD ratios at 95:5, 90:10, and 97.5:2.5 are found to be the lowest drying shrinkage at the L/B ratios of $0.40,0.5,0.60$, respectively. Differences in the trend of the FGD replacement levels are due to the characteristic of FGD. Formations of ettringite and sodium sulfate $\left(\mathrm{Na}_{2} \mathrm{SO}_{4}\right)$ are reasonable to gain low in drying shrinkage. As is observed in Figure 5, the use of $10 \%$ FGD activated with the L/B ratio of 0.50 provides low drying shrinkage.

$$
\begin{aligned}
& \mathrm{CaSO}_{4} \cdot 2 \mathrm{H}_{2} \mathrm{O}+\mathrm{NaOH} \rightarrow 4 \mathrm{Ca}(\mathrm{OH})_{2}+\mathrm{Na}_{2} \mathrm{SO}_{4} \\
& \mathrm{CaMg}\left(\mathrm{CO}_{3}\right)_{2}+2 \mathrm{NaOH} \rightarrow \mathrm{CaCO}_{3}+\mathrm{Mg}(\mathrm{OH})_{2}+\mathrm{Na}_{2} \mathrm{CO}_{3} \\
& \mathrm{Na}_{2} \mathrm{CO}_{3}+\mathrm{Ca}(\mathrm{OH})_{2} \rightarrow 2 \mathrm{CaCO}_{3}+2 \mathrm{NaOH} \\
& \mathrm{Mg}(\mathrm{OH})_{2}+\mathrm{CO}_{2} \rightarrow \mathrm{MgCO}_{3}+\mathrm{H}_{2} \mathrm{O}
\end{aligned}
$$


Regarding the use of DLM in the AAFA paste, the dedolomitization reaction is illustrated in Eqs. (2) and (3) as reported by Garcia et al [39]. When dolomite $\left(\mathrm{CaMg}\left(\mathrm{CO}_{3}\right)_{2}\right)$ activated with $\mathrm{NaOH}$ solution, formations of calcium carbonate $\left(\mathrm{CaCO}_{3}\right)$, magnesium hydroxide $\left(\mathrm{Mg}(\mathrm{OH})_{2}\right)$ and sodium carbonate $\left(\mathrm{Na}_{2} \mathrm{CO}_{3}\right)$ were formed. This is why the drying shrinkage of the AAFA paste could reduce except the paste with 10\%DLM (see Figures 7-9), indicating that there is a turning point of the DLM addition. The high content of DLM corresponds to high magnesium hydroxide $\left(\mathrm{Mg}(\mathrm{OH})_{2}\right)$ in the matrix [26]; hence, magnesium hydroxide $\left(\mathrm{Mg}(\mathrm{OH})_{2}\right)$, known as "alkali-carbonate reaction", caused the increasing volume and expansion of the hardened matrix. Besides, magnesium hydroxide $\left(\mathrm{Mg}(\mathrm{OH})_{2}\right)$ reacts with $\mathrm{CO}_{2}$ to form magnesium carbonate $\left(\mathrm{MgCO}_{3}\right)$ and $\mathrm{H}_{2} \mathrm{O}$ as shown in Eq. (4) [40].

From the test results obtained, it can be summarized that the L/B ratio of 0.40 exhibits lowest drying shrinkage of the AAFA paste with FGD and DLM as the expansive additive at ranges between 90 to 360 days. Therefore, they were selected to investigate the experiments of setting time and compressive strength of the AAFA paste.

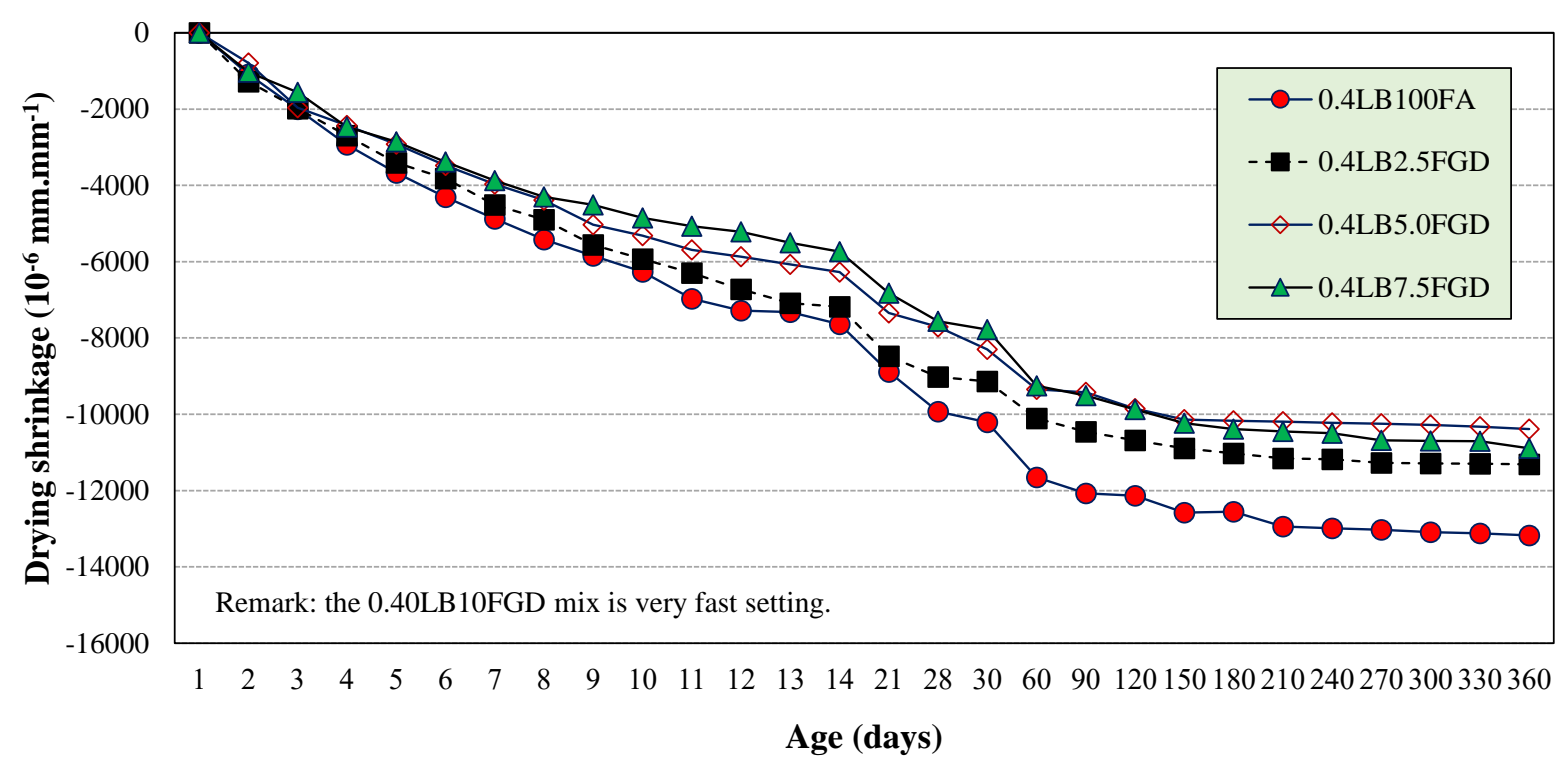


Figure 4 Drying shrinkage of alkali-activated FA paste at various FGD contents for $\mathrm{L} / \mathrm{B}$ of 0.40

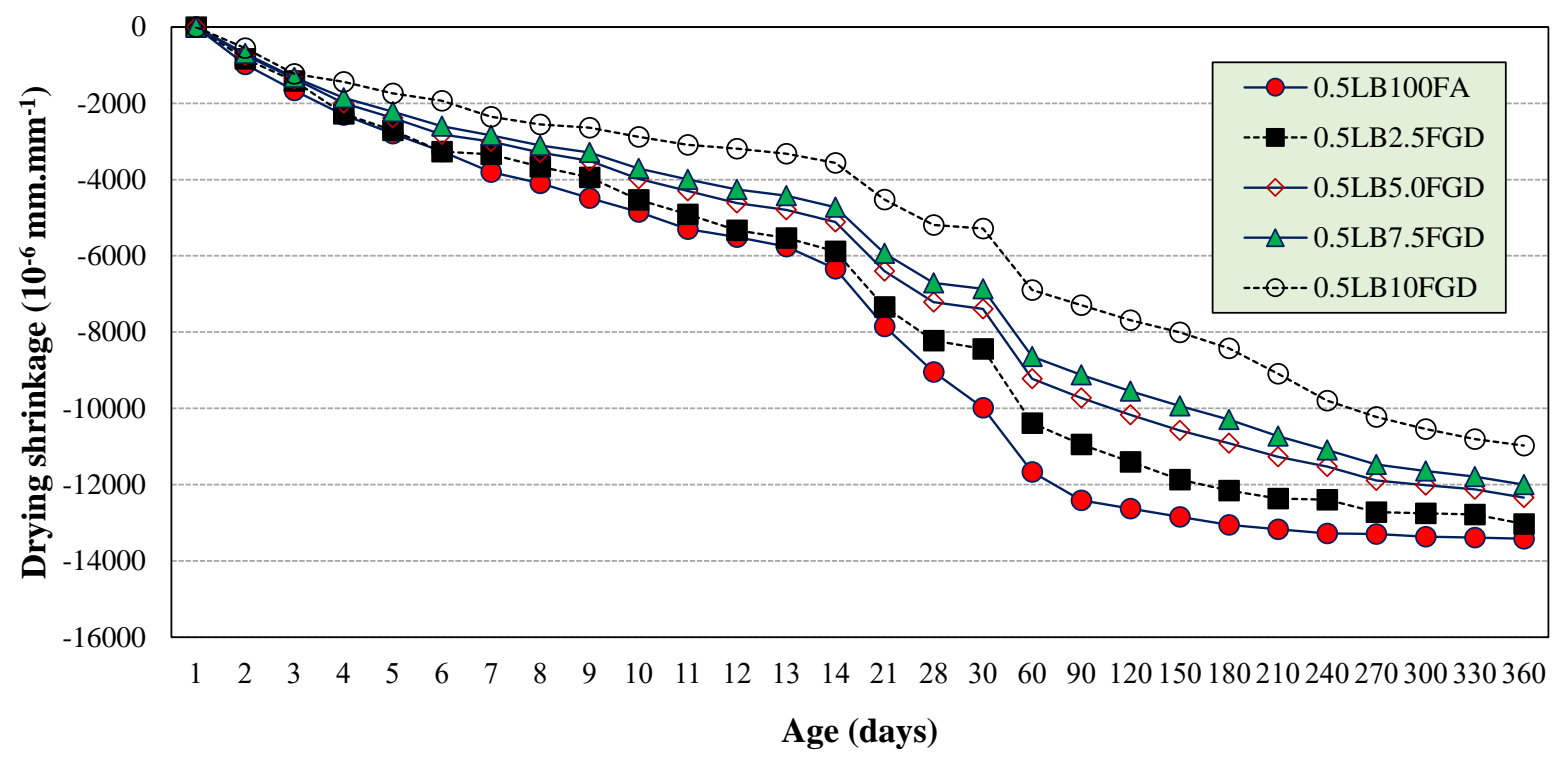

Figure 5 Drying shrinkage of alkali-activated FA paste at various FGD contents for $\mathrm{L} / \mathrm{B}$ of 0.50

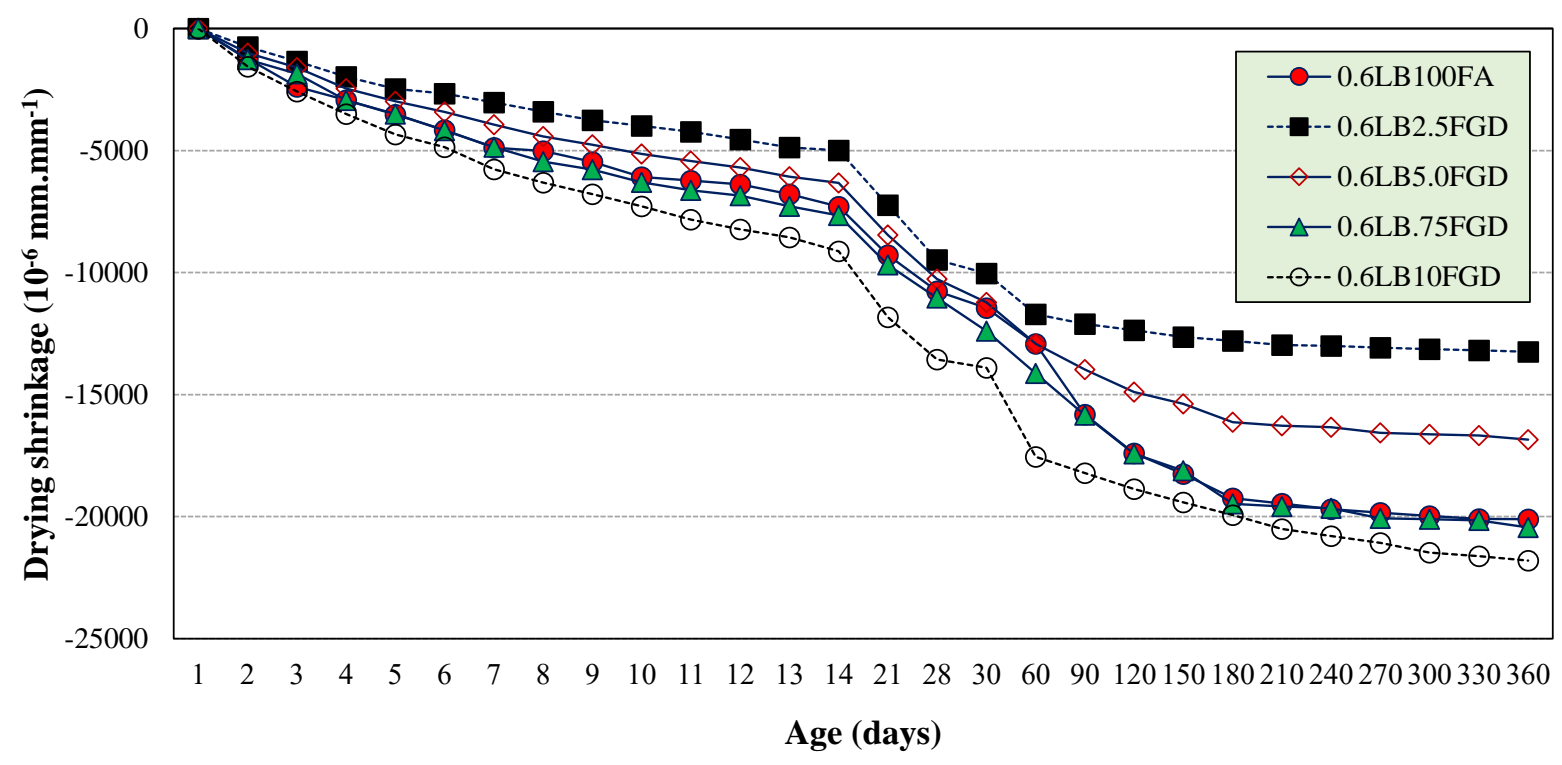

Figure 6 Drying shrinkage of alkali-activated FA paste at various FGD contents for $\mathrm{L} / \mathrm{B}$ of 0.60 


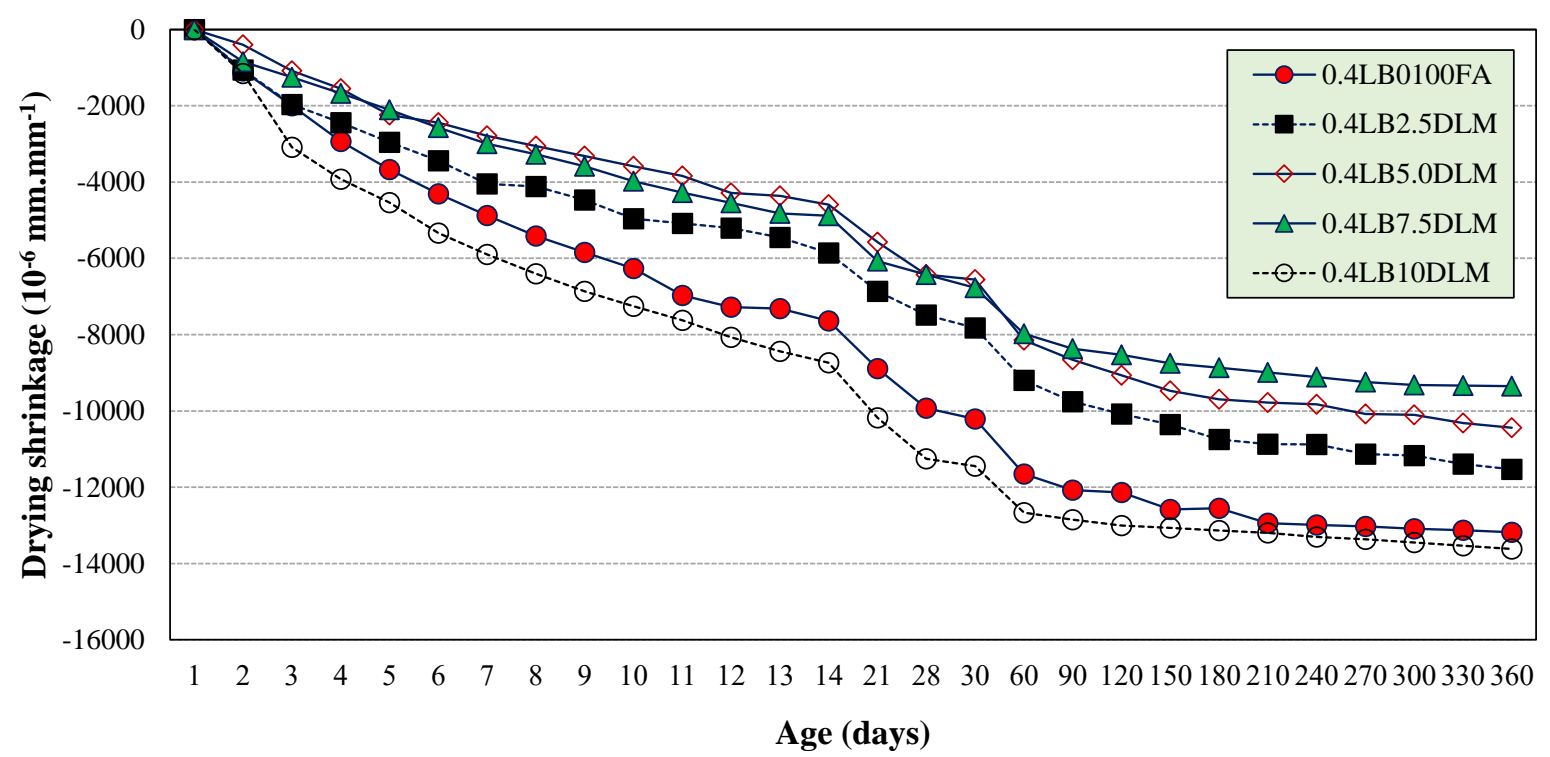

Figure 7 Drying shrinkage of alkali-activated FA paste at various DLM contents for $\mathrm{L} / \mathrm{B}$ of 0.40

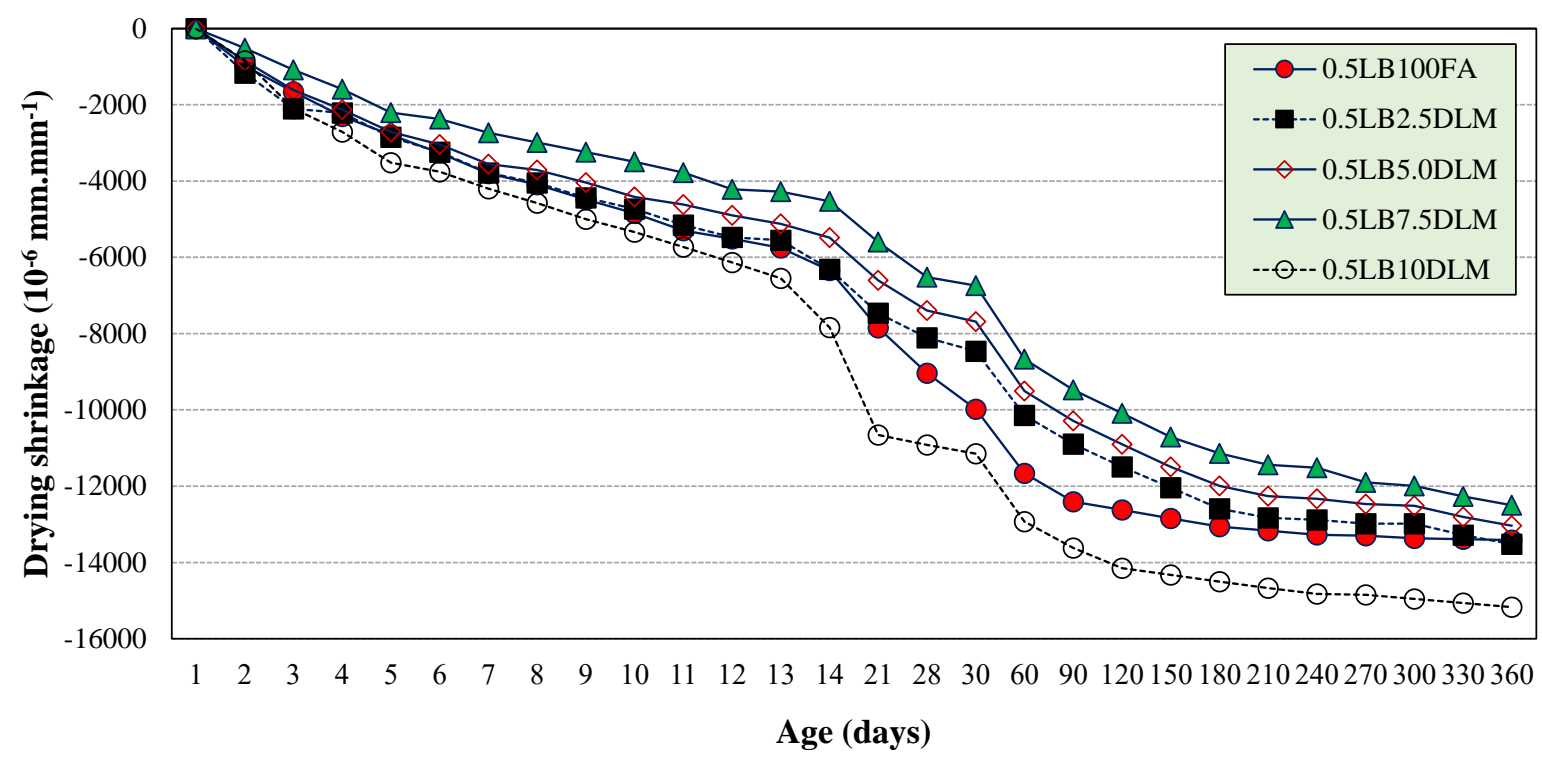

Figure 8 Drying shrinkage of alkali-activated FA paste at various DLM contents for $\mathrm{L} / \mathrm{B}$ of 0.50 


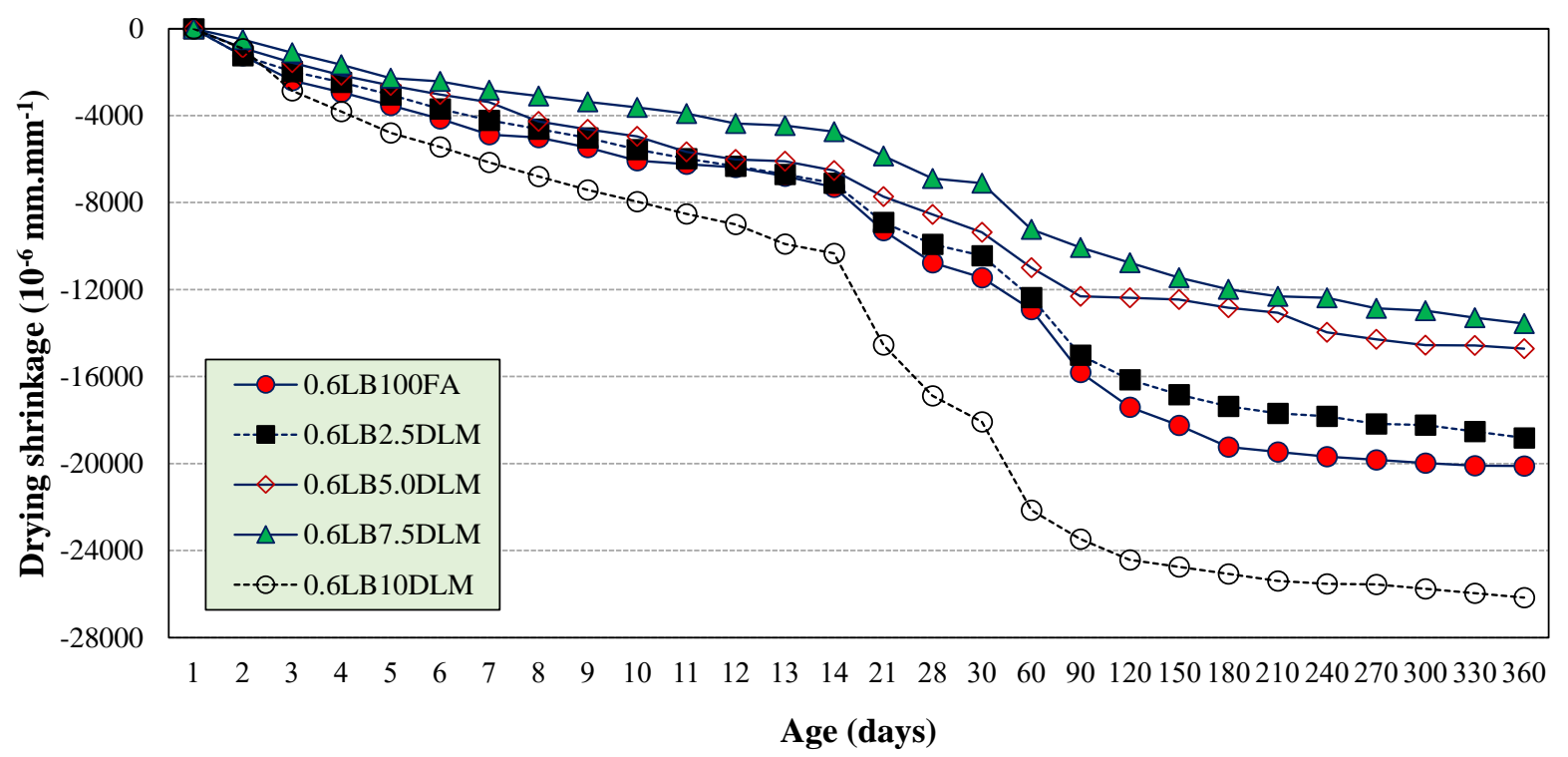

Figure 9 Drying shrinkage of alkali-activated FA paste at various DLM contents for $\mathrm{L} / \mathrm{B}$ of 0.60

\subsection{Setting time}

Figure 10 shows the change in the setting time of the AAFA paste as a function of FGD and DLM contents. The initial and final setting times of the AAFA paste obviously decrease with increasing content of FGD and DLM. They are 5-8 min and 9-13 min for the AAFA pastes with FGD, and 7-9 min and 10-14 min for the AAFA pastes with DLM. While the initial and final setting times of 100FA are $12 \mathrm{~min}$ and $18 \mathrm{~min}$, respectively. The presence of $\mathrm{Ca}$ in the raw materials is an essential factor, which provides the formation of C-S-H within the matrix $[34,41]$. A number of researchers, for example [12, 17, 36, 42-45], reported that the $\mathrm{CaO}$ was the main factor that generates heat within the matrix and hence accelerates the geopolymerization process. Chindaprasirt et al. [46] and Phoo-ngernkham et al. [43] demonstrated that the increase in $\mathrm{CaO}$ content corresponded to a decrease of the $\mathrm{SiO}_{2} / \mathrm{Al}_{2} \mathrm{O}_{3}$ ratio. As mentioned in [47], this could lead to higher reaction degree within the matrix. 
Comparing the use of FGD and DLM for producing the AAFA paste, using FGD exhibits the faster setting time of paste than that of DLM, implying that the $\mathrm{CaSO}_{4} \cdot 2 \mathrm{H}_{2} \mathrm{O}$ from FGD had very high dissolution compared with that of $\mathrm{CaMg}\left(\mathrm{CO}_{3}\right)_{2}$ from DLM. Rattanasak et al. [48] claimed that the solubility constant $\left(\mathrm{K}_{\mathrm{sp}}\right)$ of calcium hydroxide $\left(\mathrm{Ca}(\mathrm{OH})_{2}\right)$ and calcium carbonate $\left(\mathrm{CaCO}_{3}\right)$ could explain the results of setting time and compressive strength. Note that the formations of calcium hydroxide $\left(\mathrm{Ca}(\mathrm{OH})_{2}\right)$ and calcium carbonate $\left(\mathrm{CaCO}_{3}\right)$ were obtained by the reaction products as shown in Eqs. (1) and (2). As reported, $\mathrm{K}_{\mathrm{sp}}$ of $\mathrm{Ca}(\mathrm{OH})_{2}$ was $7.9 \times 10^{-6}$, whereas $\mathrm{K}_{\mathrm{sp}}$ of $\mathrm{CaCO}_{3}$ was $3.8 \times 10^{-6}$; therefore, higher $\mathrm{K}_{\mathrm{sp}}$ value could accelerate the reaction degree within the paste. In addition, Rattanasak et al. [48] demonstrated that the reaction degree of $\mathrm{Mg}(\mathrm{OH})_{2}$ as obtained by Eq. (2) could dissolve lower than $\mathrm{Ca}(\mathrm{OH})_{2}$ as obtained by Eq. (1). Note that the fast setting of the AAFA pastes with FGD and DLM as the expansive additive is advantageous for repair material as specified by ASTM C881/C881M-14 [49].

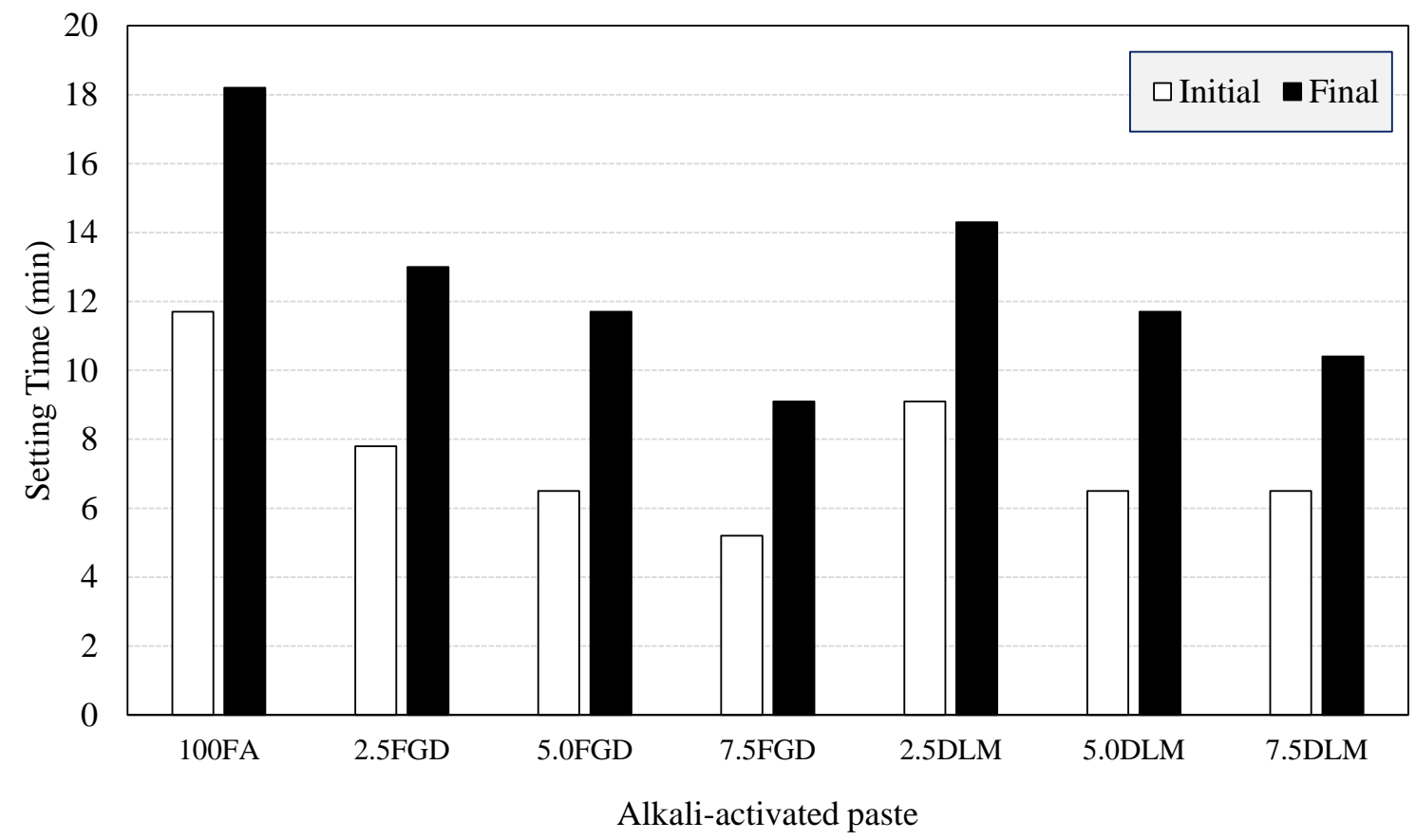

Figure 10 Setting time of alkali-activated FA paste under the best contents of FGD and DLM at $\mathrm{L} / \mathrm{B}$ ratio of 0.40 


\subsection{Compressive strength}

Figures 11-12 show the results of the compressive strength of the AAFA paste using FGD and DLM as the expansive additive. The compressive strength of the AAFA pastes tends to increase with the increase of FGD until a turning point. For example, 28-day strengths of 100FA, 2.5FGD, 5.0FGD, and 7.5FGD are 45.9, 50.2, 54.2, and 48.8 MPa, whereas 90-day strengths are 53.2, 57.9, 59.7, and 56.9 MPa, respectively. The strength increase of the AAFA containing FGD is due to the $\mathrm{CaO}$ oxide from FGD that could react with $\mathrm{SiO}_{2}$ and $\mathrm{Al}_{2} \mathrm{O}_{3}$ from FA and hence become C-S-H and/or C-A-S-H. Besides, the $\mathrm{Ca}(\mathrm{OH})_{2}$ from reaction products (see Eq. (1)) reacts with $\mathrm{SiO}_{2}$ and/or $\mathrm{Al}_{2} \mathrm{O}_{3}$ from FA to form pozzolanic reaction like the blended cement paste. Similarly, the dissolution of $\mathrm{Al}^{3+}$ ions from FA increased by the reaction of $\mathrm{SO}_{4}^{2-}$ ions as reported by Boonserm et al. [50] and Ma et al. [51]. Differences in the trend of strength development of the AAFA paste with FGD could observe at the curing times of 180 days, implying that the strength development of the paste with FGD starts to decline compared to those of 120-day strength. For example, 120-day strengths of 100FA, 2.5FGD, 5.0FGD, and 7.5FGD are 58.0, 60.8, 63.1, and 60.8 MPa, whereas 180-day strengths are 60.2, 60.7, 60.3, and 55.6 MPa, respectively. As noticed in Eq. (1), FGD consists of sodium sulfate $\left(\mathrm{Na}_{2} \mathrm{SO}_{4}\right)$; therefore, this reaction may further cause structural degradation of specimens. Also, ettringite formation $\left(\mathrm{Ca}_{6} \mathrm{Al}_{2}\left(\mathrm{SO}_{4}\right)_{3}(\mathrm{OH})_{12} .26 \mathrm{H}_{2} \mathrm{O}\right)$ had adverse effects on the specimens of AAFA paste, causing the expansion and/or cracking of specimens [38] and hence strength reduction.

Regarding the effect of using DLM in the AAFA paste, it is found that the increasing replacement levels of DLM enhance the strength development of the AAFA paste until the curing time of 180 days. For example, 120-day strengths of 2.5DLM, 5.0DLM, and 7.5DLM are 48.0, 53.3, and 55.9, whereas 180-day strengths are 64.5, 68.8, and 66.5 MPa, respectively. The noticeable increase in strength development is because the presence of $\mathrm{CaO}$ oxide from DLM assists the hardening with the addition of C-S-H and/or C-A-S-H, and coexisted with 
N-A-S-H or geopolymer gel [20, 52]. Furthermore, Yip et al. [25] claimed that the $\mathrm{Mg}^{2+}$ ions played a similar role to $\mathrm{Ca}^{2+}$ ions, implying that $\mathrm{MgO}$ from $\mathrm{DLM}$ reacts with $\mathrm{SiO}_{2}$ from $\mathrm{FA}$ to form magnesium silicate hydrate (M-S-H). The existence of $\mathrm{M}-\mathrm{S}-\mathrm{H}$ and $\mathrm{C}-\mathrm{S}-\mathrm{H}$ within the matrix contributed to the strength development of the AAFA paste [27, 28]. In addition, the chemical reaction of $\mathrm{CO}_{3}^{2-}$ ions in $\mathrm{NaOH}$ solution became calcium carbonate $\left(\mathrm{CaCO}_{3}\right)$, resulting in filling up the pore structure as reported by Ye et al. [53]. According to Figure 12, it is found that the strength development of AAFA paste incorporated with 7.5\%DLM tends to drop compared to that of 5.0\%DLM since the curing time of 120 days. Yip et al. [25] demonstrated that a small amount of carbonate material could enhance the strength development of geopolymer binder at the later stage. As reported by Yip et al. [25], mixing of $20 \%$ calcite and $20 \%$ dolomite in metakaolin-based geopolymers could enhance its strength development. However, in this study, the use of 5\% DLM provides the high performance of the AAFA paste. The difference in precursors used for producing alkali-activated binders is an important reason. Therefore, the recommended expansive additive using in AAFA paste is DLM, which provides the long-term strength and low shrinkage of the AAFA paste, although 7.5\%DLM is still higher than that of the 100FA paste.

From the test results, it can be summarized that the use of 5.0\%FGD and 7.5\%DLM as the expansive additive activated with the L/B ratio of 0.40 for producing the AAFA paste has been selected. This is because they show the highest 90-day compressive strength of the AAFA paste as desired, although the use of 5\%DLM is advantageous in term of long-term strength. For this reason, they were selected to investigate the experiments of XRD, SEM/EDS, and FTIR for an observation of the development of geopolymerization products and to understand the effect of expansive additive. 


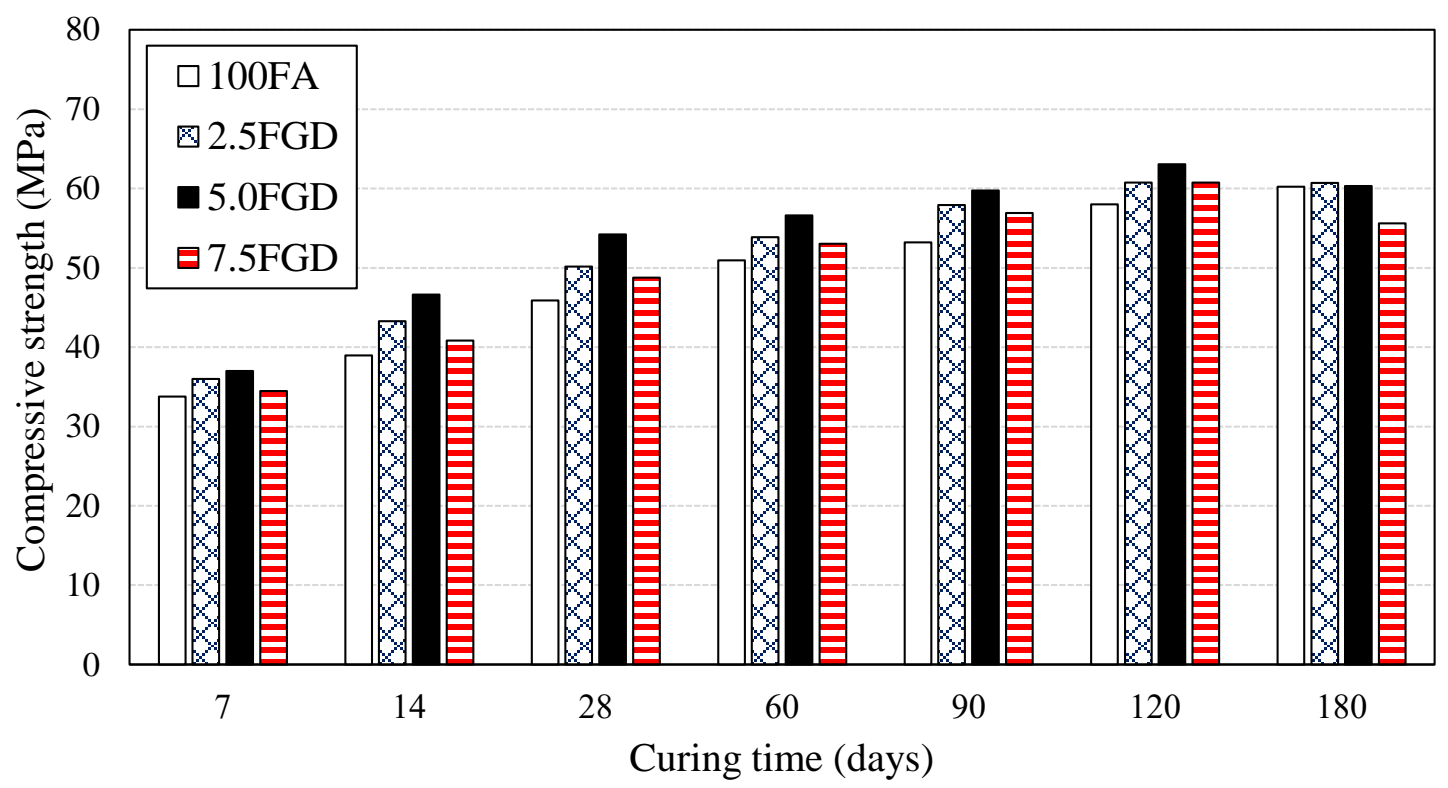

Figure 11 Compressive strength of alkali-activated FA paste under FGD contents at L/B ratio of 0.40

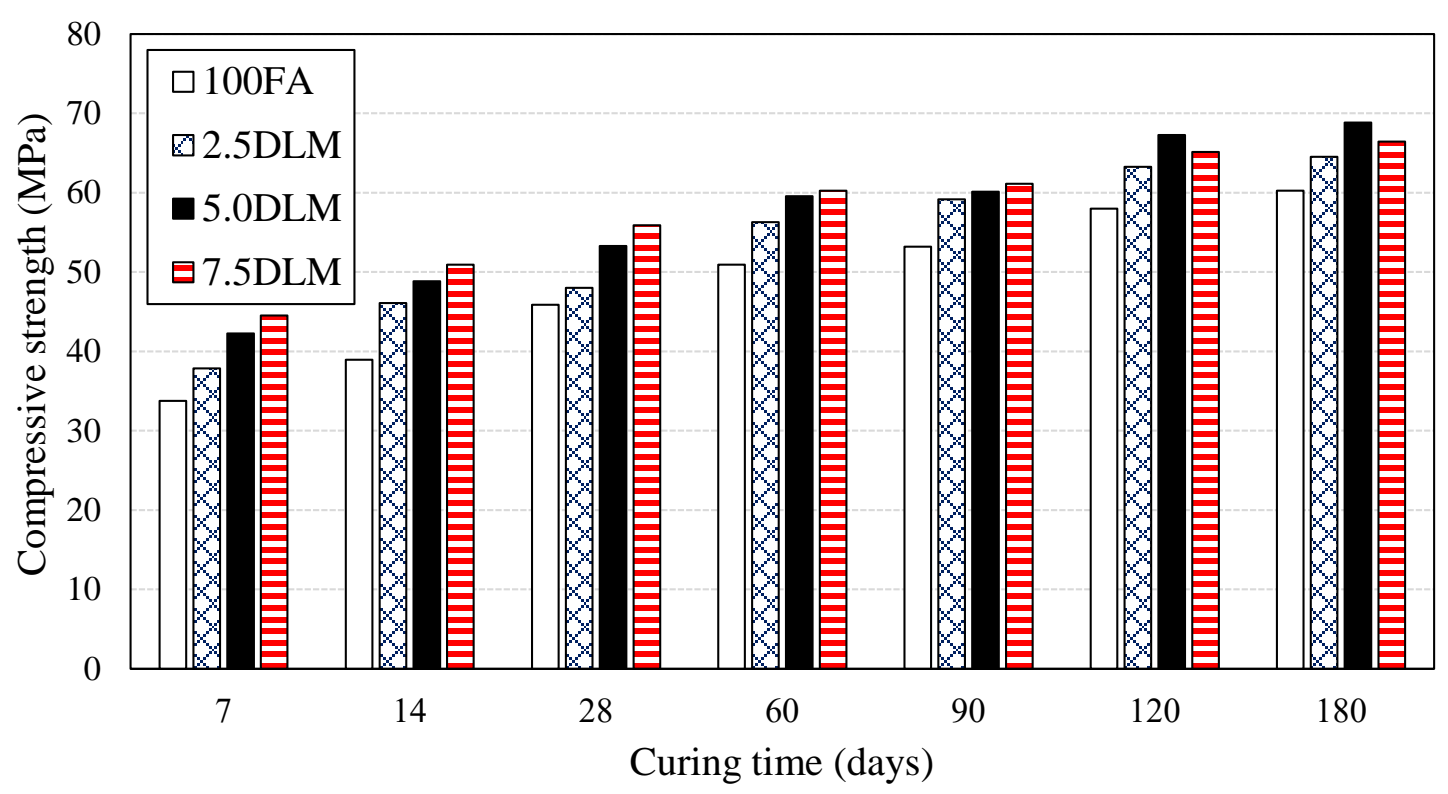

Figure 12 Compressive strength of alkali-activated FA paste under DLM contents at L/B ratio of 0.40

\subsection{XRD analysis}

The XRD patterns of the AAFA paste incorporated with FGD and DLM as the expansive additive at curing time of 90 days are shown in Figure 13. The AAFA paste without 
expansive additive (Figure 13a) consists of amorphous phase at the hump around $25-40^{\circ}$ 2theta and crystalline phases of quartz $\left(\mathrm{SiO}_{2}\right)$, ferric oxide $\left(\mathrm{Fe}_{2} \mathrm{O}_{3}\right)$, calcium carbonate $\left(\mathrm{CaCO}_{3}\right)$, and calcium silicate hydrate $(\mathrm{C}-\mathrm{S}-\mathrm{H})$. The presence of $\mathrm{C}-\mathrm{S}-\mathrm{H}$ in the XRD pattern associated to the strength development of high-calcium based geopolymer which coexisted with N-A-S-H gel $[16,34,46,54]$. When the paste containing FGD and DLM, the XRD patterns of 5.0\%FGD (Figure 13b) and 7.5\%DLM (Figure 13c) still consist of amorphous phase at the hump around $25-40^{\circ}$ 2theta and crystalline phases of quartz $\left(\mathrm{SiO}_{2}\right)$, ferric oxide $\left(\mathrm{Fe}_{2} \mathrm{O}_{3}\right)$, calcium carbonate $\left(\mathrm{CaCO}_{3}\right)$, and calcium silicate hydrate $(\mathrm{C}-\mathrm{S}-\mathrm{H})$. According to Figures $13 \mathrm{~b}$ and $13 \mathrm{c}$, the board peak at $30^{\circ} 2$ theta tends to be evident when compared to that of the 100FA paste. Moreover, the peaks of calcium silicate hydrate $(\mathrm{C}-\mathrm{S}-\mathrm{H})$ and calcium carbonate $\left(\mathrm{CaCO}_{3}\right)$ are obviously evident. This is why its strength development increases.

A comparison between FGD and DLM is investigated and it is found that the peaks of calcium silicate hydrate $(\mathrm{C}-\mathrm{S}-\mathrm{H})$ and calcium carbonate $\left(\mathrm{CaCO}_{3}\right)$ of the AAFA paste with DLM at $30^{\circ}$ 2theta are higher than those of the AAFA paste with FGD. This is because the DLM mainly consists of calcium carbonate $\left(\mathrm{CaCO}_{3}\right)$ and dolomite $\left(\mathrm{CaMg}\left(\mathrm{CO}_{3}\right)_{2}\right)$. Also, the reaction between dolomite $\left(\mathrm{CaMg}\left(\mathrm{CO}_{3}\right)_{2}\right)$ and $\mathrm{NaOH}$ solution could produce the formation of calcium carbonate $\left(\mathrm{CaCO}_{3}\right)$ (see Eq. (2)) as reported by Garcia et al. [39] and Tong and Tang [55]. In addition, sodium carbonate $\left(\mathrm{Na}_{2} \mathrm{CO}_{3}\right)$ obtained from Eq. (2) could react with calcium hydroxide $\left(\mathrm{Ca}(\mathrm{OH})_{2}\right)$ from hydration products to form the formation of calcium carbonate $\left(\mathrm{CaCO}_{3}\right)$ [39]. The occurrence of high calcium carbonate $\left(\mathrm{CaCO}_{3}\right)$ content may be advantageous regarding the strength development and drying shrinkage of the AAFA paste with DLM at the later stage. 


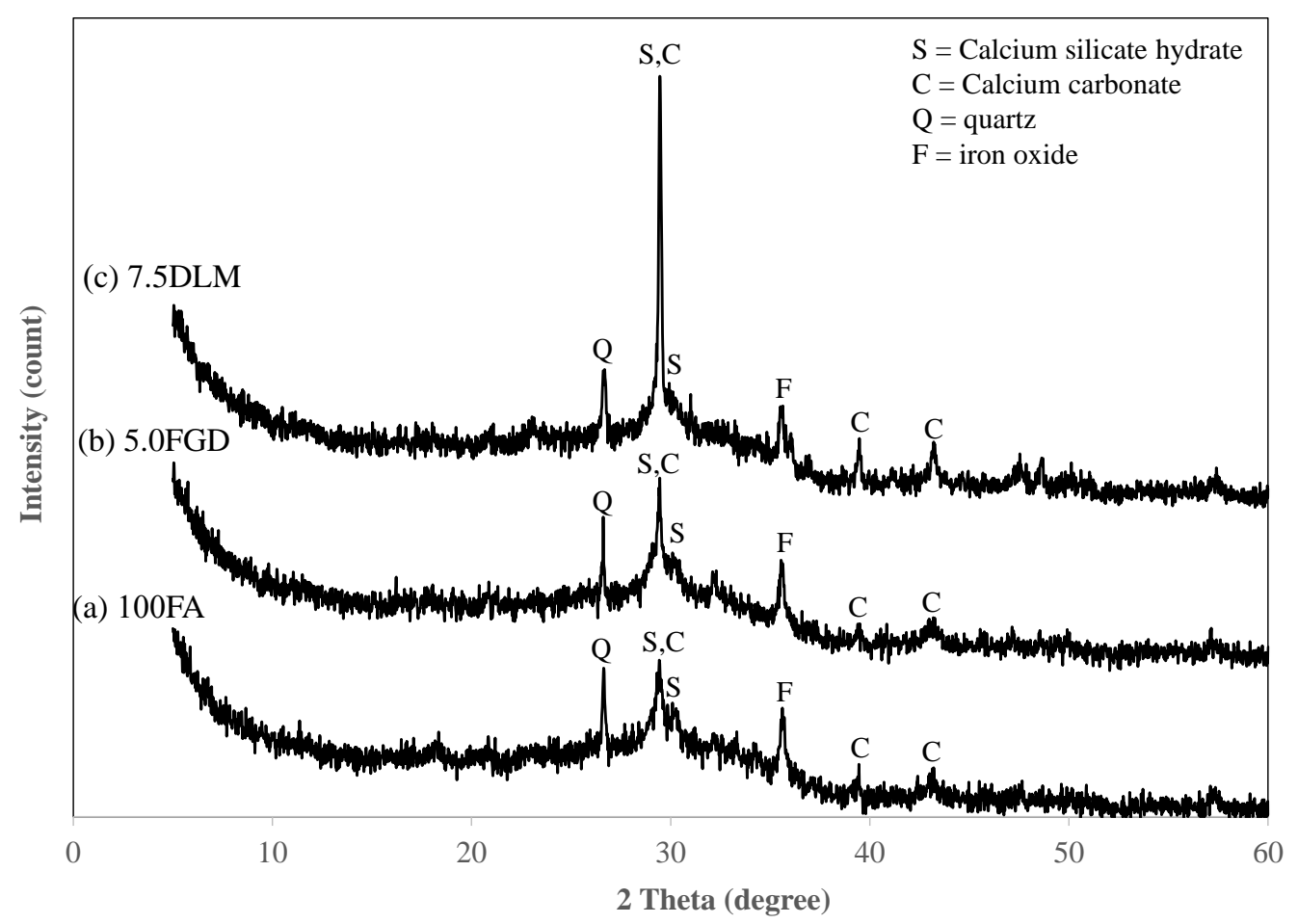

Figure 13 XRD patterns of alkali-activated FA paste containing FGD and DLM at 90 days

\subsection{FTIR analysis}

Figure 14 shows the results of FTIR spectroscopic of the AAFA paste with FGD and DLM as the expansive additive at curing time of 90 days. The strength development of alkaliactivated binder can be explained by the degree of geopolymerization via the FTIR analysis. The considerable broad band located at $3700-2200 \mathrm{~cm}^{-1}$ and $1700-1600 \mathrm{~cm}^{-1}$ were assigned to $\mathrm{O}-\mathrm{H}$ stretching and $\mathrm{O}-\mathrm{H}$ bending of water molecule, respectively, as reported by Panias et al. [56] and Boonserm et al. [50]. The spectra located at $1400-1450 \mathrm{~cm}^{-1}$ represented the carbonate $\left(\mathrm{CO}_{3}{ }^{2-}\right)$ band [57], whereas a combination of C-S-H and N-A-S-H gel was located at 900 and $1200 \mathrm{~cm}^{-1}$ [57-59]. In addition, the unreacted $\mathrm{SiO}_{2}$ in the matrix was located at approximately $460 \mathrm{~cm}^{-1}[60]$.

According to Figure 14, the wave number at approximately $3350 \mathrm{~cm}^{-1}$ and $1640 \mathrm{~cm}^{-1}$ had marginal change, implying that the precursors reacted with an alkali solution as expected. 
Similarly, the 100FA, 5.0FGD, and 7.5DLM pastes had marginal change regarding the degree of geopolymerization in the matrix as observed at approximately $945 \mathrm{~cm}^{-1}$. This is because these mixes were selected based on low shrinkage and highest strength as mentioned previously. However, at the wave number of approximately $460 \mathrm{~cm}^{-1}$, the unreacted $\mathrm{SiO}_{2}$ of the 7.5DLM paste exhibits less than those of the 100FA and 5.0FGD pastes. This behavior corresponds to the results of XRD patterns (see Figure 13). On the other hand, the 7.5DLM paste is easily identified which is related to the peak of calcium carbonate $\left(\mathrm{CaCO}_{3}\right)$ in $\mathrm{XRD}$ results (see Figure 13c). Yip et al. [25] claimed that the use of a small amount of dolomite $\left(\mathrm{CaMg}\left(\mathrm{CO}_{3}\right)_{2}\right)$ for producing the alkali-activated binders could improve the long-term strength and hence the carbonate $\left(\mathrm{CO}_{3}{ }^{2-}\right)$ might easily be detected in the matrix. According to Figure 14, the $\mathrm{SO}_{4}{ }^{2-}$ bonding has been detected at approximately $600 \mathrm{~cm}^{-1}$ for the paste with FGD (Figure 14b). This result agrees with the work of Boonserm et al. [50], who reported the improved geopolymerization of bottom ash and FA by using FGD as an additive. The presence of $\mathrm{SO}_{4}{ }^{2-}$ bonding has adverse effects on the strength development of the AAFA paste with FGD at the curing time of 120 days (see Figure 11).

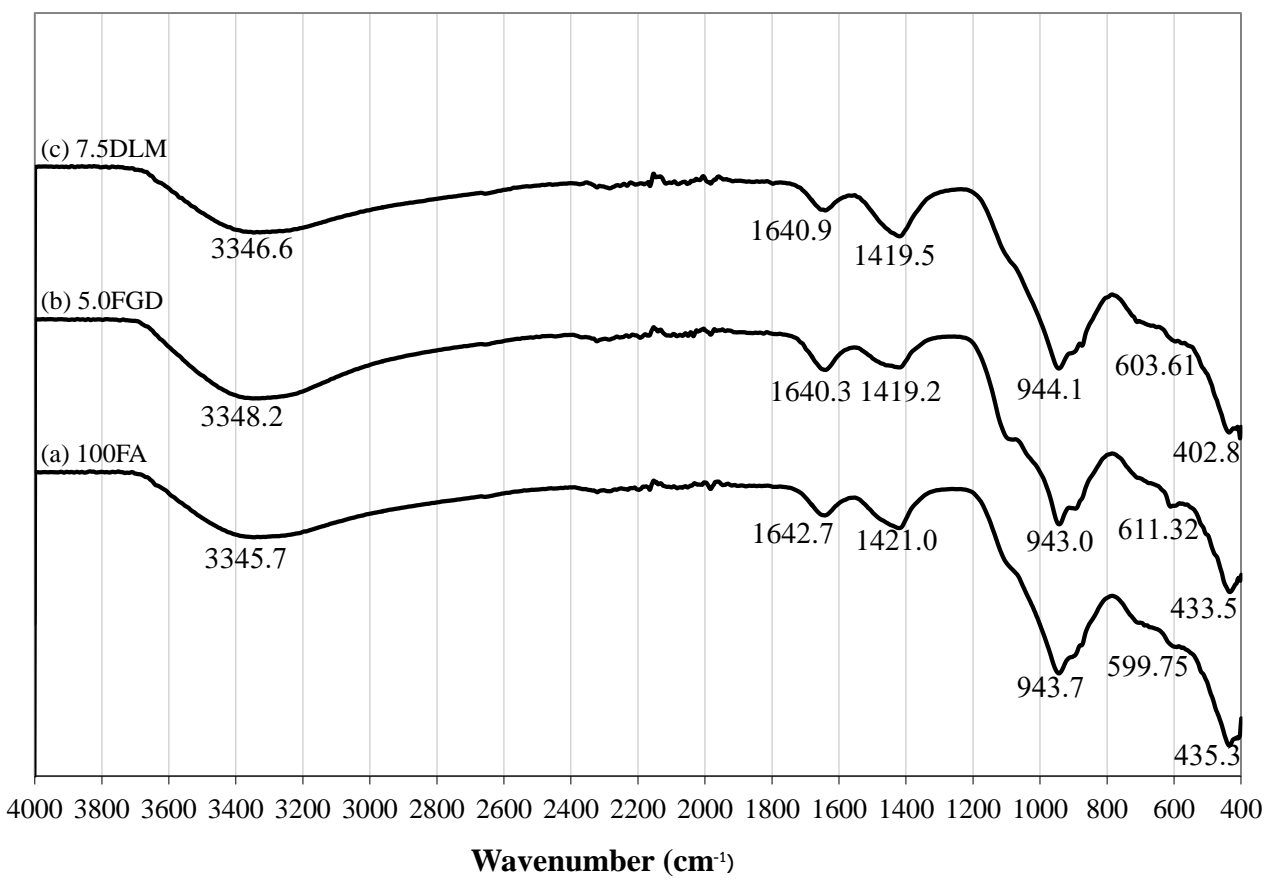


Figure 14 FTIR spectra of alkali-activated FA paste containing FGD and DLM at 90 days

\subsection{SEM and EDS analysis}

The results of SEM and EDS images of the AAFA paste with FGD and DLM as the expansive additive at curing time of 90 days are illustrated in Figures 15-16. All samples exhibit gel formation adjacent FA particles and some non-reacted and/or partially reacted FA particles embedded in a continuous matrix. The existence of calcium oxide in the system results in the development of C-S-H coexisted with N-A-S-H gel which is related to peaks of $\mathrm{C}-\mathrm{S}-\mathrm{H}$ in the XRD patterns. According to Figure 15, the AAFA pastes incorporated with FGD (Figure 15c) and DLM (Figure 15e) seem to be denser than that of the AAFA paste without the expansive additive (Figure 15a). As shown in Figure 15b, the regular-shape product of C-S-H is obviously seen on the FA particles of the 100FA paste. For the 5.0FGD paste (Figure 15d), a large amount of needle-shape products, known as the formation of "ettringite", is obviously noticed; however, the formation of ettringite is difficult to be detected by the XRD pattern [37]. Chinadaprasirt et al. [37] claimed that the formations of calcium aluminate monosulfate $\left(3 \mathrm{CaO} \cdot \mathrm{Al}_{2} \mathrm{O}_{3} \cdot \mathrm{CaSO}_{4} \cdot 12 \mathrm{H}_{2} \mathrm{O}\right)$ and calcium sulfate $\left(\mathrm{CaSO}_{4}\right)$ would be obtained from the formation of ettringite $\left(\mathrm{Ca}_{6} \mathrm{Al}_{2}\left(\mathrm{SO}_{4}\right)_{3}(\mathrm{OH})_{12} \cdot 26 \mathrm{H}_{2} \mathrm{O}\right)$ in the matrix. Thus, it is a negative factor for the strength development of the AAFA paste at the later stage. For the paste with 7.5DLM (Figure 15f), the reaction products obtained from the dedolomitization process in alkali solution were formed, and hence they coexisted with those of C-S-H, C-A-S-H, and N-A-S-H gel [61]. As seen from Figure 15f, the appearance of calcium carbonate $\left(\mathrm{CaCO}_{3}\right)$ and magnesium hydroxide $\left(\mathrm{Mg}(\mathrm{OH})_{2}\right)$ is obviously seen on the FA particles. In addition, the formation of C-S-H gel is also observed. This could explain why they had enhanced strength development. 
In order to understand the reaction products within the matrix, the EDS analysis was performed on the 100FA, 5.0FGD, and 7.5DLM pastes. It is indicated that the main elements in the products viz., $\mathrm{Na}, \mathrm{Mg}, \mathrm{Al}, \mathrm{Si}, \mathrm{Ca}$, and $\mathrm{Fe}$ are detected. The presence of $\mathrm{Na}, \mathrm{Si}$, and $\mathrm{Al}$ confirm that $\mathrm{N}-\mathrm{A}-\mathrm{S}-\mathrm{H}$ gel exists in the matrix, which is produced from the geopolymerization process. Likewise, the existence of $\mathrm{Ca}, \mathrm{Si}$, and $\mathrm{Al}$ represented the reaction products of $\mathrm{C}-\mathrm{S}-\mathrm{H}$ and C-A-S-H gel. For the 100FA paste, it has the Si/Al ratios of 2.02, 1.82, 3.47, and 0.29 for spectrum 1, 2, 3, and 4, respectively. Besides, the $\mathrm{Ca} / \mathrm{Si}$ ratio of the 100FA paste exhibits a low value, which is related to its chemical composition (see Table 1). Song et al. [62] demonstrated that the low $\mathrm{Ca} / \mathrm{Si}$ ratio represented the beginning reaction between $\mathrm{Ca}^{2+}$ and $\mathrm{Si}^{4+}$ ions in alkali solutions to form C-S-H gel. When the paste contains FGD and DLM, the variations in $\mathrm{Ca} / \mathrm{Si}$ ratio are obtained. The $\mathrm{Ca} / \mathrm{Si}$ ratios ranged between $0.84-0.91$ and 0.71 1.25 for FA-FGD and FA-DLM pastes, respectively. This is in agreement with the studies of Gue et al. [63] and $\mathrm{Li}$ et al. [15] that the $\mathrm{Ca} / \mathrm{Si}$ ratio at the beginning hydration was approximately 1.0. As revealed in Figures $16 \mathrm{~b}$ and $16 \mathrm{c}$, the Si/Al ratios vary between 2.162.33 and 2.88-2.91 for FA-FGD and FA-DLM pastes, respectively. The $\mathrm{Ca} / \mathrm{Si}$ ratio of the AAFA paste with DLM agreed with the works of Punurai et al. [20] and Gue et al. [41]. They claimed that the $\mathrm{Si} / \mathrm{Al}$ ratio in the ranges of 2.6 - 3.0 provided a high strength development of high-calcium based geopolymer. According to spectrum 1 in Figure 16b, a high amount of Al was found; therefore, ettringite formation had taken place, in which the needle-shape products occurred. For spectrum 1 in Figure 16c, the elements of $\mathrm{Mg}$ and $\mathrm{Ca}$ contain a high amount that corresponds to a high ratio of $\mathrm{Ca} / \mathrm{Si}$. In this case, the reaction products of dedolomitization participated in the system, and hence it might be formations of calcium carbonate $\left(\mathrm{CaCO}_{3}\right)$ and magnesium hydroxide $\left(\mathrm{Mg}(\mathrm{OH})_{2}\right)$. Considering the $\mathrm{Na} / \mathrm{Al}$ ratio, they are $0.85,0.65$, and 1.07 for spectrums 3 (Figure 16a), 4 (Figure 16b), and 3 (Figure 16c), respectively. The paste with DLM $(\mathrm{Na} / \mathrm{Al}$ ratio of 1.07$)$ is consistent with the work of Zhang 
et al. [64], who reported that the $\mathrm{Na} / \mathrm{Al}$ ratio should be 1.0. The results of EDS corresponds well to the result of their strength.

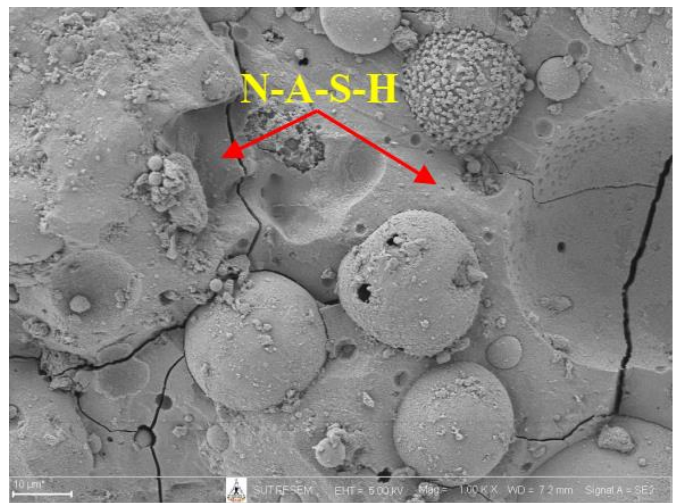

(a) $100 \mathrm{FA} \times 1,000$

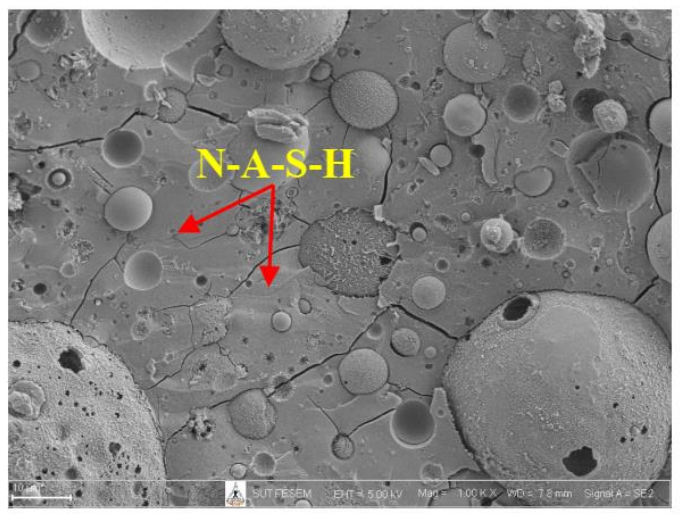

(c) $5.0 \mathrm{FGD} \times 1,000$

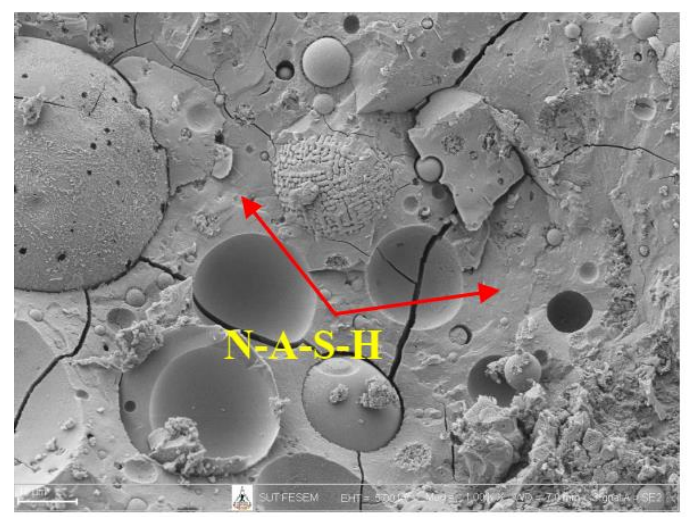

(e) 7.5DLM x1,000

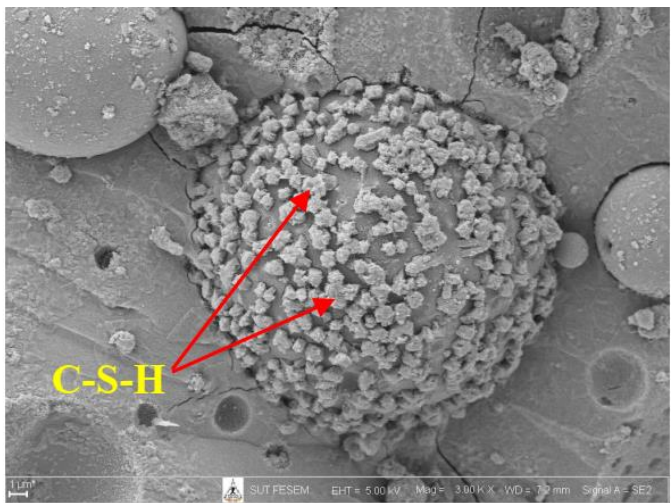

(b) 100FA x3000

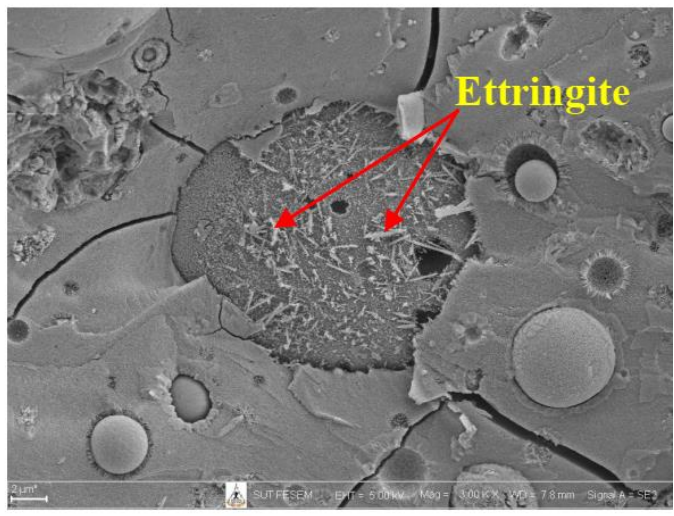

(d) 5.0FGD $\times 3000$

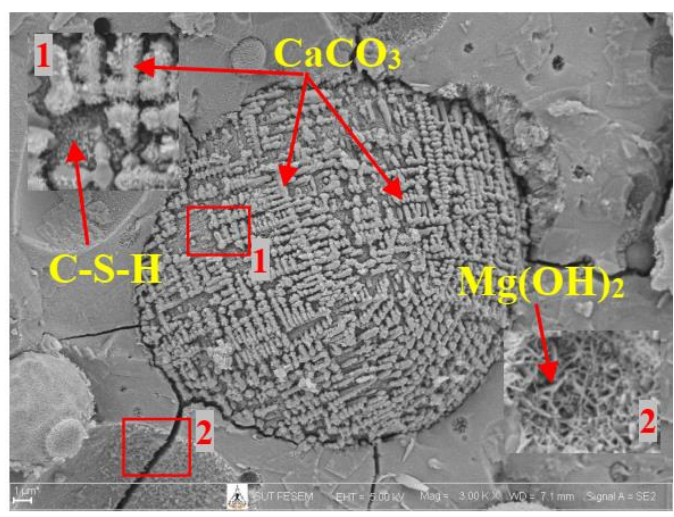

(f) 7.5DLM x3000

Figure 15 SEM images of alkali-activated FA paste containing FGD and DLM at 90 days 


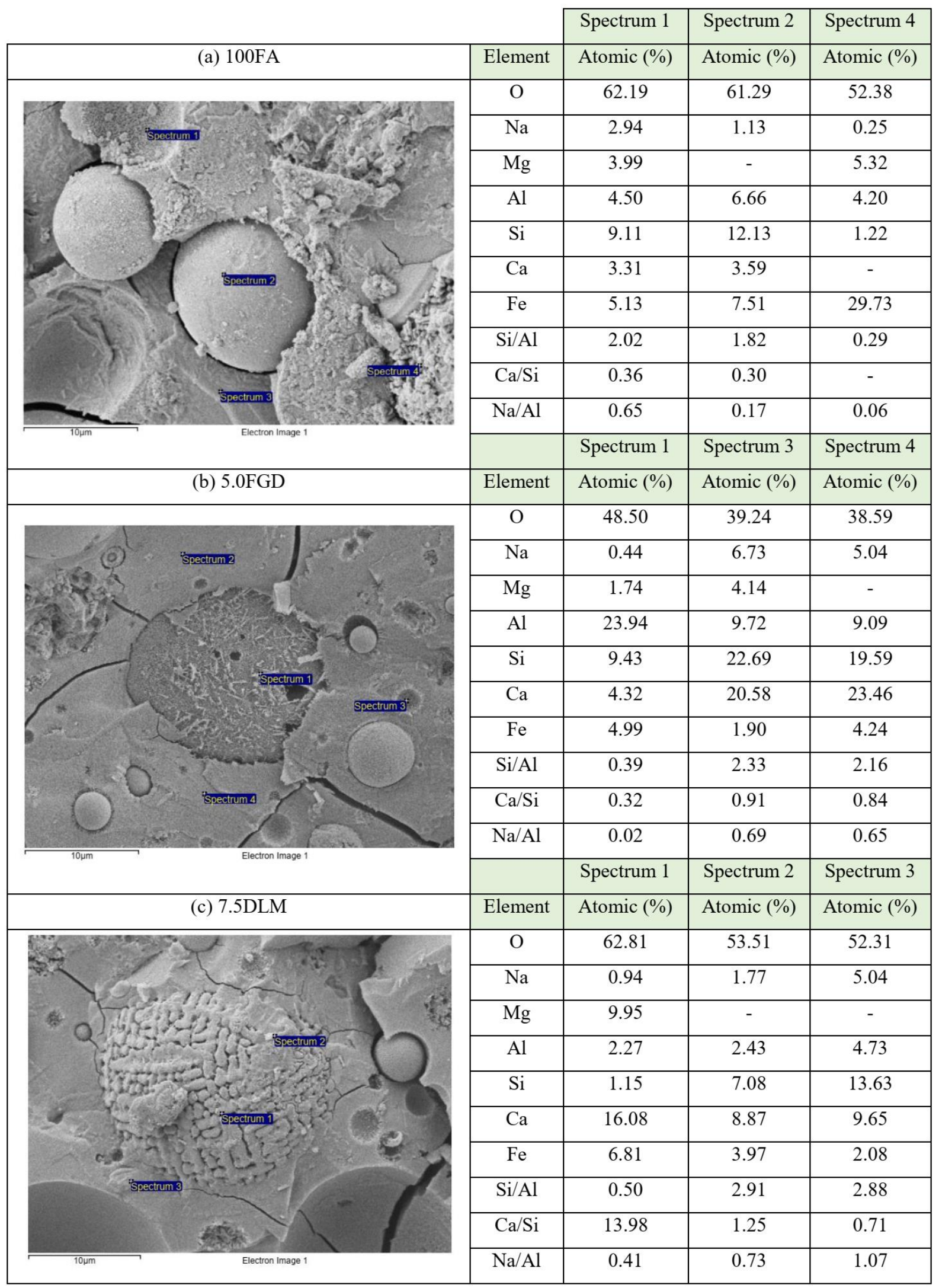

Figure 16 EDS images of alkali-activated FA paste containing FGD and DLM at 90 days 


\section{Conclusion}

This paper presents an experimental study on the drying shrinkage, strength, and microstructure of alkali-activated high-calcium FA using FGD-gypsum and dolomite as the expansive additive. Based on the obtained experimental results, the following conclusions could be drawn:

1) The drying shrinkage of alkali-activated FA paste is significantly improved with the incorporation of FGD and DLM as the expansive additive. While the increase in the L/B ratios leads to increased drying shrinkage of alkali-activated FA paste for all replacement levels of FGD and DLM. The reduction of drying shrinkage of alkali-activated FA paste incorporated with FGD and DLM was because of the reaction products of gypsum and dolomite in alkali solution.

2) The incorporation of FGD and DLM in alkali-activated FA paste resulted in a reduction in its setting time, whereas the strength development tended to increase. However, a strength reduction was found at the later stage noticed in the paste with 5.0\%FGD at the curing time of 120 days. The increase in strength was due to the addition of $\mathrm{CaO}$ oxide from FGD and DLM reacted with $\mathrm{SiO}_{2}$ and $\mathrm{Al}_{2} \mathrm{O}_{3}$ from FA that accelerate the geopolymerization process; therefore, the speedy setting time and strength development of alkali-activated FA paste were obtained.

3) The main reaction products viz., amorphous phase, C-S-H, and calcite of alkaliactivated FA paste with DLM in the XRD patterns exhibited higher value than those of the 100FA and 5.0FGD pastes. A small amount of dolomite used in the matrix could enhance the long-term strength and the existence of carbonate $\left(\mathrm{CO}_{3}{ }^{2-}\right)$ may have positive effect on its strength development. For the paste with FGD, the $\mathrm{SO}_{4}{ }^{2-}$ bonding was found in the FTIR analysis and this bonding caused a loss in strength development of paste seen at the curing time of 120 days. 
4) The SEM images of alkali-activated FA paste with DLM and FDG showed an improved microstructure in comparison with the paste without the expansive additive. Different reaction products surrounding FA particles were noticed. This includes the formations of ettringite and C-S-H were observed for FA-FGD paste; whereas the formations of $\mathrm{CaCO}_{3}$, $\mathrm{Mg}(\mathrm{OH})_{2}$, and C-S-H were seen for FA-DLM paste, which was coexisted with N-A-S-H gel. The results of EDS analysis correspond well to the results of SEM image and strength development.

5) The alkali-activated FA paste with DLM as the expansive additive is recommended for the optimum mix in terms of improved drying shrinkage and long-term strength compared with that of the paste with FGD.

\section{Acknowledgements}

This work was financially supported by the TRF New Research Scholar Grant no. MRG6180161. The authors also would like to acknowledge the support of the Program of Civil Technology, Faculty of Industrial Technology, Lampang Rajabhat University and the Department of Civil Engineering, Faculty of Engineering and Architecture, Rajamangala University of Technology Isan, Thailand. The part of the present work was also supported by the European Commission Research Executive Agency via the Marie Skłodowska-Curie Research and Innovation Staff Exchange Project (689857-PRIGeoC-RISE-2015) and the Industry Academia Partnership Programme-2 (IAPP1617\16) "Development of Sustainable Geopolymer Concrete".

\section{References}

[1] Ramli M, Akhavan T A. Effects of different curing regimes on engineering properties of polymer-modified mortar. Journal of Materials in Civil Engineering. 2012;24(4):468-78. 
[2] Turner LK, Collins FG. Carbon dioxide equivalent $\left(\mathrm{CO}_{2}-\mathrm{e}\right)$ emissions: A comparison between geopolymer and OPC cement concrete. Construction and Building Materials. 2013;43(0):125-30.

[3] McLellan BC, Williams RP, Lay J, van Riessen A, Corder GD. Costs and carbon emissions for geopolymer pastes in comparison to ordinary portland cement. Journal of Cleaner Production. 2011;19(9-10):1080-90.

[4] Sata V, Jaturapitakkul C, Kiattikomol K. Influence of pozzolan from various by-product materials on mechanical properties of high-strength concrete. Construction and Building Materials. 2007;21(7):1589-98.

[5] Sata V, Khammathit P, Chindaprasirt P. Efficiency factor of high calcium Class F fly ash in concrete. Computers and Concrete. 2011;8(5):583-95.

[6] Detphan S, Phoo-ngernkham T, Sata V, Detphan C, Chindaprasirt P. Portland cement containing fly ash, expanded perlite, and plasticizer for masonry and plastering mortars. International Journal of GEOMATE. 2018;15(48):107-13.

[7] Chindaprasirt P, Phoo-ngernkham T, Hanjitsuwan S, Horpibulsuk S, Poowancum A, Injorhor B. Effect of calcium-rich compounds on setting time and strength development of alkali-activated fly ash cured at ambient temperature. Case Studies in Construction Materials. 2018:e0198.

[8] Sukontasukkul P, Chindaprasirt P, Pongsopha P, Phoo-Ngernkham T, Tangchirapat W, Banthia N. Effect of fly ash/silica fume ratio and curing condition on mechanical properties of fiber-reinforced geopolymer. Journal of Sustainable Cement-Based Materials. 2020:1-15.

[9] Hanjitsuwan S, Phoo-ngernkham T, Li LY, Damrongwiriyanupap N, Chindaprasirt P. Strength development and durability of alkali-activated fly ash mortar with calcium carbide residue as additive. Construction and Building Materials. 2018;162:714-23. 
[10] Phoo-ngernkham T, Hanjitsuwan S, Li LY, Damrongwiriyanupap N, Chindaprasirt P. Adhesion characterization of Portland cement concrete and alkali-activated binders under different types of calcium promoters. Advances in Cement Research. 2019;31(2):69-79.

[11] Phoo-ngernkham T, Hanjitsuwan S, Suksiripattanapong C, Thumrongvut J, Suebsuk J, Sookasem S. Flexural strength of notched concrete beam filled with alkali-activated binders under different types of alkali solutions. Construction and Building Materials. 2016;127:6738.

[12] Phoo-ngernkham T, Phiangphimai C, Intarabut D, Hanjitsuwan S, Damrongwiriyanupap N, Li LY, et al. Low cost and sustainable repair material made from alkali-activated highcalcium fly ash with calcium carbide residue. Construction and Building Materials. 2020;247:118543.

[13] Pacheco-Torgal F, Castro-Gomes J, Jalali S. Alkali-activated binders: A review. Part 1. Historical background, terminology, reaction mechanisms and hydration products. Construction and Building Materials. 2008;22(7):1305-14.

[14] De Silva P, Sagoe-Crenstil K. Medium-term phase stability of $\mathrm{Na}_{2} \mathrm{O}-\mathrm{Al}_{2} \mathrm{O}_{3}-\mathrm{SiO}_{2}-\mathrm{H}_{2} \mathrm{O}$ geopolymer systems. Cement and Concrete Research. 2008;38(6):870-6.

[15] Li C, Sun H, Li L. A review: The comparison between alkali-activated slag ( $\mathrm{Si}+\mathrm{Ca})$ and metakaolin (Si+Al) cements. Cement and Concrete Research. 2010;40(9):1341-9.

[16] Phoo-ngernkham T, Chindaprasirt P, Sata V, Sinsiri T. High calcium fly ash geopolymer containing diatomite as additive. Indian Journal of Engineering \& Materials Sciences. 2013;20(4):310-8.

[17] Phoo-ngernkham T, Hanjitsuwan S, Thumrongvut J, Detphan S, Suksiripattanapong S, Damrongwiriyanupap N, et al. Shear bond strength of FA-PC geopoylmer under different sand to binder ratios and sodium hydroxide concentrations. International Journal of GEOMATE. 2018;14(52):52-7. 
[18] Phoo-ngernkham T, Sata V, Hanjitsuwan S, Ridtirud C, Hatanaka S, Chindaprasirt P. High calcium fly ash geopolymer mortar containing Portland cement for use as repair material. Construction and Building Materials. 2015;98:482-8.

[19] Ridtirud C, Chindaprasirt P, Pimraksa K. Factors affecting the shrinkage of fly ash geopolymers. International Journal of Minerals, Metallurgy, and Materials. 2011;18(1):100-4. [20] Punurai W, Kroehong W, Saptamongkol A, Chindaprasirt P. Mechanical properties, microstructure and drying shrinkage of hybrid fly ash-basalt fiber geopolymer paste. Construction and Building Materials. 2018;186:62-70.

[21] Ma Y, Ye G. The shrinkage of alkali activated fly ash. Cement and Concrete Research. 2015;68(0):75-82.

[22] Fernández-Jiménez A, Palomo A, Criado M. Microstructure development of alkaliactivated fly ash cement: a descriptive model. Cement and Concrete Research. 2005;35(6):1204-9.

[23] Matalkah F, Salem T, Shaafaey M, Soroushian P. Drying shrinkage of alkali activated binders cured at room temperature. Construction and Building Materials. 2019;201:563-70.

[24] Bakharev T, Sanjayan JG, Cheng YB. Effect of admixtures on properties of alkaliactivated slag concrete. Cement and Concrete Research. 2000;30(9):1367-74.

[25] Yip CK, Provis JL, Lukey GC, van Deventer JSJ. Carbonate mineral addition to metakaolin-based geopolymers. Cement and Concrete Composites. 2008;30(10):979-85.

[26] Cohen E, Peled A, Bar-Nes G. Dolomite-based quarry-dust as a substitute for fly-ash geopolymers and cement pastes. Journal of Cleaner Production. 2019;235:910-9.

[27] Hwang CL, Vo DH, Tran VA, Yehualaw MD. Effect of high MgO content on the performance of alkali-activated fine slag under water and air curing conditions. Construction and Building Materials. 2018;186:503-13. 
[28] Jin F, Gu K, Al-Tabbaa A. Strength and drying shrinkage of reactive MgO modified alkali-activated slag paste. Construction and Building Materials. 2014;51:395-404.

[29] ASTM C618-15. Standard specification for coal fly ash and raw or calcined natural pozzolan for use in concrete. Annual Book of ASTM Standard. 2015;Vol.04.02.

[30] ASTM C490. Standard practice for use of apparatus for the determination of length change of hardened cement paste, mortar, and concrete. Annual Book of ASTM Standard. 2017; Vol.04.01.

[31] ASTM C596. Standard test method for drying shrinkage of mortar containing hydraulic cement. Annual Book of ASTM Standard. 2017;Vol.04.01.

[32] ASTM C191-13. Standard test method for time of setting of hydrualic cement by vicat needle. Annual Book of ASTM Standard 2013;Vol.04.01.

[33] ASTM C109. Standard test method of compressive strength of hydrualic cement mortars (using 2-in. or [50 mm] cube speciments). Annual Book of ASTM Standard. 2002; Vol.04.01. [34] Hanjitsuwan S, Phoo-ngernkham T, Damrongwiriyanupap N. Comparative Study using Portland Cement and Calcium Carbide Residue as a Promoter in Bottom Ash Geopolymer Mortar. Construction and Building Materials. 2017;133:128-34.

[35] Yusuf MO, Megat Johari MA, Ahmad ZA, Maslehuddin M. Shrinkage and strength of alkaline activated ground steel slag/ultrafine palm oil fuel ash pastes and mortars. Materials \& Design. 2014;63:710-8.

[36] Pangdaeng S, Phoo-ngernkham T, Sata V, Chindaprasirt P. Influence of curing conditions on properties of high calcium fly ash geopolymer containing Portland cement as additive. Materials \& Design. 2014;53(0):269-74.

[37] Chindaprasirt P, Thaiwitcharoen S, Kaewpirom S, Rattanasak U. Controlling ettringite formation in FBC fly ash geopolymer concrete. Cement and Concrete Composites. 2013;41(0):24-8. 
[38] Zhang Y, Pan F, Wu R. Study on the performance of FGD gypsum-metakaolin-cement composite cementitious system. Construction and Building Materials. 2016;128:1-11.

[39] García E, Alfonso P, Labrador M, Galí S. Dedolomitization in different alkaline media: Application to Portland cement paste. Cement and Concrete Research. 2003;33(9):1443-8.

[40] Yusuf MO, Megat Johari MA, Ahmad ZA, Maslehuddin M. Strength and microstructure of alkali-activated binary blended binder containing palm oil fuel ash and ground blastfurnace slag. Construction and Building Materials. 2014;52(0):504-10.

[41] Guo X, Shi H, Chen L, Dick WA. Alkali-activated complex binders from class C fly ash and Ca-containing admixtures. Journal of Hazardous Materials. 2010;173(1-3):480-6.

[42] Phoo-ngernkham T, Chindaprasirt P, Sata V, Pangdaeng S, Sinsiri T. Properteis of high calcium fly ash geopolymer pastes containing Portland cement as additive. International Journal of Minerals, metallurgy and Materials. 2013;20(2):214-20.

[43] Phoo-ngernkham T, Hanjitsuwan S, Damrongwiriyanupap N, Chindaprasirt P. Effect of sodium hydroxide and sodium silicate solutions on strengths of alkali activated high calcium fly ash containing Portland cement. KSCE Journal of Civil Engineering. 2017;21(6):2202-10. [44] Phoo-ngernkham T, Maegawa A, Mishima N, Hatanaka S, Chindaprasirt P. Effects of sodium hydroxide and sodium silicate solutions on compressive and shear bond strengths of FA-GBFS geopolymer. Construction and Building Materials. 2015;91(0):1-8.

[45] Phoo-ngernkham T, Sata V, Hanjitsuwan S, Ridtirud C, Hatanaka S, Chindaprasirt P. Compressive strength, Bending and Fracture Characteristics of High Calcium Fly Ash Geopolymer Mortar Containing Portland Cement Cured at Ambient Temperature. Arabian Journal for Science and Engineering. 2016;41(4):1263-71.

[46] Chindaprasirt P, De Silva P, Sagoe-Crenstil K, Hanjitsuwan S. Effect of $\mathrm{SiO}_{2}$ and $\mathrm{Al}_{2} \mathrm{O}_{3}$ on the setting and hardening of high calcium fly ash-based geopolymer systems. Journal of Materials Science. 2012;47(12):4876-83. 
[47] Yip CK, Lukey GC, Provis JL, van Deventer JSJ. Effect of calcium silicate sources on geopolymerisation. Cement and Concrete Research. 2008;38(4):554-64.

[48] Rattanasak U, Pankhet K, Chindaprasirt P. Effect of chemical admixtures on properties of high-calcium fly ash geopolymer. International Journal of Minerals, Metallurgy, and Materials. 2011;18(3):364-9.

[49] ASTM C881/C881M-14. Standard specification for epoxy-resin-base bonding systems for concrete. Annual Book of ASTM Standard. 2014; Vol.04.02.

[50] Boonserm K, Sata V, Pimraksa K, Chindaprasirt P. Improved geopolymerization of bottom ash by incorporating fly ash and using waste gypsum as additive. Cement and Concrete Composites. 2012;34(7):819-24.

[51] Ma W, Brown PW. Hydrothermal reactions of fly ash with $\mathrm{Ca}(\mathrm{OH})_{2}$ and $\mathrm{CaSO}_{4} \cdot 2 \mathrm{H}_{2} \mathrm{O}$. Cement and Concrete Research. 1997;27(8):1237-48.

[52] Phoo-ngernkham T, Phiangphimai C, Damrongwiriyanupap N, Hanjitsuwan S, Thumrongvut J, Chindaprasirt P. A Mix Design Procedure for Alkali-Activated HighCalcium Fly Ash Concrete Cured at Ambient Temperature. Advances in Materials Science and Engineering. 2018;2018:13.

[53] Ye H, Fu C, Yang G. Influence of dolomite on the properties and microstructure of alkali-activated slag with and without pulverized fly ash. Cement and Concrete Composites. 2019;103:224-32.

[54] Chindaprasirt P, Rattanasak U. Utilization of blended fluidized bed combustion (FBC) ash and pulverized coal combustion (PCC) fly ash in geopolymer. Waste Management. 2010;30(4):667-72.

[55] Tong L, Tang M. Expansion mechanism of alkali-dolomite and alkali-magnesite reaction. Cement and Concrete Composites. 1999;21(5):361-73. 
[56] Panias D, Giannopoulou IP, Perraki T. Effect of synthesis parameters on the mechanical properties of fly ash-based geopolymers. Colloids and Surfaces A: Physicochemical and Engineering Aspects. 2007;301(1-3):246-54.

[57] Barbosa VFF, MacKenzie KJD, Thaumaturgo C. Synthesis and characterisation of materials based on inorganic polymers of alumina and silica: Sodium polysialate polymers. International Journal of Inorganic Materials. 2000;2(4):309-17.

[58] Garcia-Lodeiro I, Aparicio-Rebollo E, Fernández-Jimenez A, Palomo A. Effect of calcium on the alkaline activation of aluminosilicate glass. Ceramics International. 2016.

[59] Alvarez-Ayuso E, Querol X, Plana F, Alastuey A, Moreno N, Izquierdo M, et al. Environmental, physical and structural characterisation of geopolymer matrixes synthesised from coal (co-)combustion fly ashes. Journal of Hazardous Materials. 2008;154(1-3):175-83. [60] Rattanasak U, Chindaprasirt P. Influence of $\mathrm{NaOH}$ solution on the synthesis of fly ash geopolymer. Minerals Engineering. 2009;22(12):1073-8.

[61] Chindaprasirt P, Rattanasak U. Characterization of the high-calcium fly ash geopolymer mortar with hot-weather curing systems for sustainable application. Advanced Powder Technology. 2017;28(9):2317-24.

[62] Song S, Sohn D, Jennings HM, Mason TO. Hydration of alkali-activated ground granulated blast furnace slag. Journal of Materials Science. 2000;35(1):249-57.

[63] Guo X, Shi H, Dick WA. Compressive strength and microstructural characteristics of class C fly ash geopolymer. Cement and Concrete Composites. 2010;32(2):142-7.

[64] Zhang L, Ahmari S, Zhang J. Synthesis and characterization of fly ash modified mine tailings-based geopolymers. Construction and Building Materials. 2011;25(9):3773-81. 